\title{
DETERMINANTES E IMPACTOS DA RECENTE ENTRADA DE BANCOS EUROPEUS NO BRASIL
}

\author{
Luiz Fernando de Paula ${ }^{1}$
}

\section{INTRODUÇÃo}

O objetivo deste artigo é analisar os principais determinantes e impactos da recente onda de bancos europeus no Brasil. A principal hipótese do artigo é que a onda de bancos europeus só pode ser entendida se forem considerados ambos os fatores externos e internos. Os determinantes externos estão relacionados ao processo de consolidação bancária no sistema financeiro europeu no contexto da União Monetária Européia, que tem estimulado alguns bancos a se expandirem para o exterior. A expansão para o exterior não é somente uma forma de diversificação de ganhos para esses bancos, mas também um caminho para eles fortalecerem sua posição no mercado bancário europeu sob a pressão da unificação econômica e monetária. Os determinantes internos, por sua vez, estão principalmente relacionados à gradual flexibilização das restrições legais com respeito a presença dos bancos estrangeiro no setor bancário brasileiro, no contexto da crise bancária de 1995 .

$\mathrm{O}$ artigo também avalia os impactos da entrada recente dos bancos europeus no mercado bancário varejista brasileiro. Neste particular, ele mostra que a entrada estrangeira tem afetado o mercado bancário doméstico, forçando os bancos nacionais a operarem de forma mais eficiente e também a expandir suas atividades, organicamente ou por fusões e aquisições. O paper conclui

1 Professor da Faculdade de Ciências Econômicas da Universidade do Estado do Rio de Janeiro (FCE/UERJ) e pesquisador do CNPq. O apoio do PRONEX/CNPq/ FAPERJ é reconhecido. Ifpaula@alternex.com.br 
que não existe evidência de que os bancos estrangeiros são mais eficientes do que os bancos domésticos no Brasil no período recente, mas existe alguma evidência de que os maiores bancos privados nacionais têm reagido positivamente a entrada dos bancos estrangeiros. Bancos privados nacionais são ainda hegemônicos comparados aos bancos estrangeiros, embora a participação relativa dos bancos estrangeiros tenha crescido significativamente nos últimos anos. Eles têm respondido a esse ambiente mais competitivo buscando tornar-se mais eficientes e participando agressivamente das recentes fusões e aquisições (F\&As), particularmente (mas não exclusivamente) na privatização dos bancos estaduais.

$\mathrm{O}$ artigo está dividido em cinco seções, além desta introdução. A seção 2 examina o processo de consolidação da indústria bancária européia no contexto da UME, com ênfase no recente processo de consolidação bancária européia. A seção 3 analisa, com base na literatura existente, as estratégias de expansão dos bancos multinacionais. A seção 4 analisa os determinantes das estratégias de expansão dos bancos europeus no Brasil, assim como a estratégia de expansão dos quatro maiores bancos europeus na América Latina - BSCH, BBVA, HSBC e ABN-Amro. A seção 5 examina a reação dos três grandes bancos privados nacionais - Bradesco, Itaú e Unibanco - à recente entrada de bancos estrangeiros no mercado bancário brasileiro. A seção final sumariza os principais argumentos do texto.

\section{CONSOLIDAÇÃO NO SETOR BANCÁRIO EUROPEU NO CONTEXTO DA UNIÃO MONETÁRIA EUROPÉIA}

O Programa de Mercado Único e a União Monetária Européia (UME) podem ser vistos como redutores de barreiras de eficiência para consolidação bancária dentro das fronteiras da União Européia, e dentro do subconjunto de nações participantes da União Monetária, respectivamente. De fato, essas políticas podem reduzir ou eliminar as diferenças entre moeda, estruturas regulatórias e, ainda, as regras explícitas contra competidores estrangeiros por parte dos países da União Européia, o que torna, em tese, mais fácil e menos custoso para as instituições financeiras operarem por meio das fronteiras entre países dentro da União Européia (EU) (BERGER et al., 2000a, p. 9). Portanto, a Lei do Mercado Único criou, teoricamente, as mesmas oportunidades para a atividade de F\&As e de concentração bancária que ocorreu recentemente nos EUA.

O euro, em particular, pode desempenhar um papel importante na zona do euro ao reforçar os fatores que têm conduzindo o processo de 
consolidação no setor bancário europeu. Com a adoção da moeda única é de se esperar um aumento na competição entre as instituições financeiras, reduzindo as barreiras à entrada, diminuindo o risco cambial (devido à redução nos custos de conversão da moeda) e reduzindo os custos para os consumidores comprarem serviços das instituições estrangeiras. Uma vez que a moeda única levanta as barreiras econômicas relativas à oferta de serviços bancários entre fronteiras dentro da zona do euro, a sua adoção tem o potencial de expandir a capacidade de crescimento e de diversificação dos bancos no bloco. Como a adoção do euro acarreta, em princípio, uma intensificação na competição bancária, ela pode reforçar o incentivo para se criar instituições capazes de competir efetivamente em uma escala pan-européia. Sua influência tem fortalecido a tendência em direção a instituições maiores que sejam capazes de obter os plenos benefícios de maiores economias de escala, trazidos tanto pelo aumento na escala de produção quanto pelo progresso técnico (BIS, 2000, p. 134).

De forma geral, podemos destacar, a partir Belaisch et al. (2001) e Molyneux (2000), como tendências nos mercados bancários da Área Econômica Européia ${ }^{2}$ na última década, algumas características que são de alguma forma similares àquelas referentes à indústria bancária global:

- $\quad$ existe uma queda na quantidade de instituições de crédito na maioria dos membros da $\mathrm{UE}^{3}$ : todos os países, com exceção de Portugal, experimentaram um declínio no número de bancos desde o final dos anos 80, mas, ao mesmo tempo, o número de bancos estrangeiros tem aumentado. A redução no número de instituições de crédito na maioria dos países pode ser atribuída às fusões e incorporações, embora outras formas de saída de mercado - tais como liquidação - podem também ter contribuído para esse declínio;

- uma tendência comum não pode ser identificada em termos do número de agências bancárias, embora em alguns dos maiores mercados bancários (Alemanha, Itália e Espanha) o número de agência tenha proliferado durante os anos 90. Por outro lado, o número de empregados declinou de 1995 para 1999, particularmente na Finlândia e no Reino Unido;

2 Inclui, além dos países da zona do euro, Reino Unido, Suécia e Dinamarca, ou seja, todos os países da UE.

3 De acordo com Bis (2000, p. 45), o número de instituições depositárias (banco comerciais, de poupança, mútuos e cooperativas de crédito) na zona do euro caiu de 9.445 em 1980 para 7.040 em 1997. 
- a concentração de mercado tem aumentado na maioria dos países europeus, e nos sistemas bancários dos menores países, a participação dos 5 maiores bancos no setor tipicamente excede $50 \%$ do total de ativos, empréstimos e depósitos. Conseqüentemente, o grau de concentração no topo é particularmente elevado nos menores países membros da $\mathrm{UE}^{4}$, onde atualmente um pequeno número de bancos domina o setor bancário; ${ }^{5}$

- embora os sistemas bancários da Área Econômica Européia estejam se tornando mais concentrados, por meio de fusões de grandes instituições, a concentração permanece em mãos domésticas. A participação dos bancos estrangeiros dentro dos mercados domésticos é pequena nas quatro maiores economias da zona do euro. ${ }^{6}$ Eles são significantes apenas na Bélgica, Irlanda e Luxemburgo, onde o market share das subsidiárias das instituições bancárias estrangeiras como percentagem do total de ativos no final de 1997 era 36,3\%, 53,6\% e 94,6\%, respectivamente (BELAISCH et al., 2001, p. 17);

- a consolidação tem se acelerado recentemente no topo do setor bancário, uma vez que mais da metade dos 30 maiores bancos da zona do euro são resultado de recentes fusões e o tamanho médio dos 5 maiores tem dobrado desde 1995. ${ }^{7}$ Conseqüentemente, o tamanho médio dos 30 maiores grupos bancários da zona do euro pulou de US\$ 114,9 bilhões em 1990 para US\$ 321,0 bilhões em 1999 (ver tabela 1). Assim, as F\&As estão alterando profundamente a estrutura do setor bancário europeu, com impactos no ranking dos maiores grupos bancários;

- existe um declínio nas margens líquidas de juros - a diferença entre as receitas dos bancos oriundas dos empréstimos e a

4 As exceções são Irlanda, Áustria e Luxemburgo.

5 De acordo com informações de Belaisch et al. (2001, p. 16), a participação dos 5 maiores bancos no total de ativos bancários em 1998 era de $89,7 \%$ na Bélgica; $69,5 \%$ na Espanha; 69,3\% na Irlanda; 63,3\% nos Países Baixos; e 51,5\% na Áustria.

6 A participação estrangeira dentro dos mercados domésticos (total de ativos) era no final de 1997, 4,3\% na Alemanha, 9,8\% na França, 6,8\% na Itália, e 11,7\% na Espanha (BELAISCH et al., 2001, p. 17).

7 Cerca de 500 fusões e aquisições foram realizadas em 1991/1992 na zona do euro, no montante total de US\$ 17,5 bilhões, enquanto que, em 1997/1999, somente 200 F\&As foram realizadas, no montante de cerca de US\$110,0 bilhões - um número menor de F\&As mas em escala bem maior (BELAISCH et al., 2001, p. 14). 
remuneração dos depósitos bancários - em virtualmente todos sistemas bancários dos países da UE, possivelmente como resultado de pressões competitivas crescentes sobre o setor bancário. A desregulamentação dos serviços da indústria bancária na região nos últimos 15 anos tem aumentado consideravelmente a competição no setor bancário e reduzido o papel de intermediação financeira tradicional como a principal fonte de receita dos bancos. De fato, entre 1992 e 1998, a margem líquida de juros na zona do euro (média da região) tem declinado de 2,0 para 1,5\% do total de ativos dos bancos (BELAISCH et al., 2001, p. 22);

- conseqüentemente, os bancos têm, de forma crescente, focado sua atenção sobre o aumento das receitas não-juros como fonte de rendimentos, deslocando parcialmente os ganhos com juros como principal fonte de receitas dos bancos. ${ }^{8}$ No Reino Unido, Áustria, Finlândia, França e Suécia cerca de $40 \%$ da receita bruta do sistema bancário foi derivada de receitas de origem não-juros em 1996, enquanto que na Alemanha e na Noruega entre $20-25 \%$ da receita bruta proveio de fontes de receitas não-juros, já que estes países têm uma forte tradição de terem bancos adiantando crédito para indústria e outros clientes (MOLYNEUX, 2000, p. 6). Em particular, a expansão de comissões bancárias tem sido principalmente baseada no grande crescimento dos fundos mútuos, uma linha de negócios em que os bancos, na maioria dos países da zona do euro, têm assegurado um proeminente papel;

- a lucratividade do setor bancário nos diferentes países apresenta um quadro misto, embora na maioria dos países os retornos tenham melhorado, a despeito do declínio na eficiência bancária. O desenvolvimento das atividades relacionadas às receitas nãojuros podem ter tido um efeito positivo sobre o desempenho

8 É interessante notar, entretanto, que o sistema financeiro na zona do euro continua a ser dominado pelos bancos. De acordo com a explicação de Belaisch et al. (2001, p. 6), "ao contrário dos Estados Unidos, onde os bancos comerciais têm somente recentemente sido capazes de emitir fundos mútuos e vender produtos de seguros, o crescimento de novos veículos de poupança está substituindo os rendimentos tradicionais dos bancos universais na zona do euro, e, por isso, as receitas não são necessariamente perdidas para outros intermediários financeiros". 
dos bancos, ainda que a lucratividade permaneça de modo geral mais baixa do que nos Estados Unidos. ${ }^{9}$

Molyneux (2000) conclui que enquanto os mercados bancários dos países da UE têm se tornado crescentemente concentrados, o número de bancos têm diminuído. Por outro lado, ainda que não exista nenhuma tendência óbvia de queda no desempenho bancário nos diferentes países, a competição parece ter se intensificado na zona do euro, uma vez que a desregulamentação e as mudanças tecnológicas têm tornado os mercados bancários mais contestáveis. Como resultado da maior competição, o ritmo da consolidação financeira na Europa acelerou-se recentemente, provavelmente em antecipação da introdução da nova moeda. As forças motoras do processo de consolidação na Área Econômica Européia, que estão mudando a estrutura do setor bancário europeu, incluem, entre outras, tecnologia da informação, desintermediação financeira e integração dos mercados internacionais de capital, onde a criação da moeda única desempenha um papel essencial.

Como pode ser visto na tabela 2 , as fusões e aquisições financeiras não têm se restringido às linhas da indústria bancária, mas estão também freqüentemente fora destas, em particular em operações envolvendo duas instituições financeiras não-bancárias ou bancos comprando companhias de seguro, presumivelmente devido à popularidade do bancassurance e à ausência de barreiras legais. Entretanto, as instituições bancárias têm se expandido mais ativamente para outros setores da indústria financeira do que outras instituições financeiras no negócio bancário. ${ }^{10}$ Pode ser também visto que as fusões e aquisições permanecem em boa medida confinadas dentro das fronteiras nacionais, contrastando com o pequeno volume de negócios envolvendo outros países participantes da UME. Portanto, tem havido significativa consolidação doméstica com instituições bancárias assim como expressiva atividade de F\&As envolvendo corretoras de títulos e seguradoras nos países da UE, mas pouca consolidação internacional envolvendo bancos europeus dentro da Área Econômica Européia.

9 De acordo com dados do Bis (2000, p. 44), o retorno sobre ativos, em média, na zona do euro cresceu de $0,55 \%$ em 1996 para $0,63 \%$ em 1998 , enquanto que nos EUA ele caiu de $1,83 \%$ para $1,42 \%$ no mesmo período.

10 Como ressalta o estudo feito por European Central Bank (2000, p. 14), "isto pode ser devido às barreiras à entrada que historicamente são mais altas no setor bancário do que no setor de seguros. E também pode ser devido ao fato de que em muitos estados membros [da União Européia] a indústria bancária é bem mais desenvolvida do que a indústria de seguros". 
A atividade atual de consolidação bancária entre países na UE tem tomado freqüentemente a forma de alianças estratégicas, muitas vezes reforçadas pela aquisição de participações minoritárias e não-controladoras, como ilustrado pela aliança entre BSCH e Royal Bank of Scotland. Assim, a consolidação bancária na Área Econômica Européia, especialmente no mercado varejista, tem ocorrido predominantemente dentro das fronteiras nacionais mais do que entre países. Banqueiros em geral acreditam que uma posição forte no mercado doméstico é crucial para uma expansão bem-sucedida no exterior. De fato, como assinala o relatório do European Central Bank (2000, p. 5), "parece que em muitos países, os grupos bancários têm procurado primeiro consolidar sua posição dentro das fronteiras nacionais antes de

Tabela 1 - OS 31 MAIORES GRUPOS BANCÁRIOS DA ZONA DO EURO - 1990/1999 (EM TERMOS DE TOTAL DE ATIVOS EM US\$ MILHÕES)

\begin{tabular}{|c|c|c|c|c|c|}
\hline & 1990 & & 1995 & & 1999 \\
\hline Crédit Agricole & 241992 & Deutsche Bank & 368261 & Deutsche Bank + Bankers Trust ${ }^{\star}$ & $\overline{732534}$ \\
\hline BNP & 231463 & Crédit Agricole & 328152 & BNP Paribas* & 688361 \\
\hline Crédit Lyonnais & 210727 & Crédit Lyonnais & 327903 & ABN-Amro* & 504122 \\
\hline Deutsche Bank & 202263 & ABN-Amro & 290835 & Hypovereinsbank* & 504122 \\
\hline Sociéte Générale & 164741 & Sociéte Générale & 278006 & Crédit Agricole + Indosuez* & 455792 \\
\hline Caisses d'Epargne & 152722 & BNP & 271635 & Sociéte Générale & 447545 \\
\hline Dresdner Bank & 147001 & Dresdner Bank & 253818 & Dresdner Bank & 427261 \\
\hline Paribas & 138668 & Paribas & 242219 & Westdeutsche Land Giro & 408372 \\
\hline Commerzbank & 112825 & Westdeutsche Land Giro & 237535 & Commerzbank & 381359 \\
\hline DG Bank & 109168 & Commerzbank & 220704 & ING Bank Group* & 326813 \\
\hline IBSanPaolo & 107403 & Bayerische Vereinsbank & 204423 & Fortis* & 323567 \\
\hline Westdeutsche Landesbank Giro & 104508 & Caisses d'Epargne & 187411 & Rabobank Netherlands & 291353 \\
\hline Bayerische Vereinsbank & 102191 & Bayerische Hypotheken \& Wechsel & 177540 & Crédit Mutuel + $\mathrm{CIC}^{\star}$ & 284461 \\
\hline $\mathrm{BNL}$ & 100967 & Bayerische Landesbank & 171816 & Bayerische Landesbank & 284064 \\
\hline Amro Bank & 93824 & Krediteanstalt fur Wiederaufbau & 158736 & $\mathrm{BSCH}^{\star}$ & 258872 \\
\hline Bayerische Landesbank & 90855 & DG Bank & 158227 & DG Bank & 248297 \\
\hline ABN & 90411 & Bankgesellschaft Berlin & 157197 & Crédit Lyonnais & 243708 \\
\hline Bayerische Hypotheken \& Wechsel & 90129 & Rabobank Netherlands & 155082 & Banques Populaires + Natexis* & 239673 \\
\hline Rabobank Netherlands & 90016 & SanPaolo Bank Holding & 153115 & BBVA $^{*}$ & 237747 \\
\hline $\mathrm{BCl}$ & 88594 & Generale Bank & 126889 & Caisses d'Espargne & 235660 \\
\hline NMB Postbank Group & 84194 & International Nederland Bank & 125343 & Dexia $^{\star}$ & 232601 \\
\hline Cariplo & 82103 & Nordeutsche Landesbank & 118507 & Bankgesellschaft Berlin & 220646 \\
\hline Monte dei Paschi di Siena & 75694 & Banco Santander & 114174 & SanPaolo IMI* & 185403 \\
\hline Credito Italiano & 75223 & Cariplo & 107788 & Banca Intesa* & 179258 \\
\hline CIC Group & 74725 & Sudwest LB & 107602 & Unicredito Italiano* & 171730 \\
\hline BBV & 69986 & Crédit Communal de Belgique & 99941 & Nordeutsche Land Giro & 170759 \\
\hline Generale Bank & 67637 & BBV & 99174 & KBC Bank* & 163125 \\
\hline Nordeutsche Landesbank & 67515 & BNL & 98662 & Bank Austria* & 140161 \\
\hline Banques Populaires & 64701 & $\mathrm{CIC}$ & 97839 & $\mathrm{BCl}$ & 132188 \\
\hline Banque Indosuez & 55316 & Banca di Roma & 93373 & Banca di Roma & 122145 \\
\hline \multirow[t]{2}{*}{$\mathrm{BBL}$} & 50548 & $\mathrm{BCl}$ & 92449 & Merita Nordbanken* & 112049 \\
\hline & milhões & US\$ milhões & tx.cresc. & US\$ milhões & tx.cresc. \\
\hline Média & 114905 & 190739 & 66,00 & 320977 & 68,28 \\
\hline Média dos 5 maiores & 210237 & 318631 & 51,56 & 576986 & 81,08 \\
\hline Média dos 3 maiores & 228061 & 341439 & 49,71 & 641672 & 87,93 \\
\hline
\end{tabular}

FONTE: The Banker (apud BELAISCH et al., 2001, p. 15).

* Grupos bancários que resultam de recentes fusões. 
fazerem um movimento estratégico como resposta à criação do mercado único e da introdução da moeda única". Por outro lado, F\&As em geral, dentro dos países da UE, têm como meta freqüentemente a criação de grupos financeiros regionais, em que Fortis, Dexia e MerritaNordbanken são bons exemplos.

Portanto, parece haver alguns impedimentos para fusões e aquisições dentro dos países da UE, e um incentivo para tal atividade fora da região. Um desses incentivos é a ausência de uma agência regulatória única na UE, que tem limitado os benefícios para os bancos se expandirem para áreas de atividades financeiras entre países e, ao mesmo tempo, tem impedido os bancos europeus de se engajarem na diversificação de ganhos e na redução dos níveis de capital, tal como tem sido praticado nos EuA. Assim, a despeito da uniformidade que deveria ter sido criada depois da Lei do Mercado Único e das várias diretrizes das comissões bancárias e financeiras européias, e da introdução da moeda comum, dificuldades como diferentes regulamentações prudenciais nacionais têm tornado as operações entre países mais difíceis. Existem ainda múltiplas agências de supervisão dentro dos diferentes países e nenhuma agência de coordenação ou uma agência regulatória única dos

Tabela 2 - FUSÕES E AQUISIÇÕES NA INDÚSTRIA FINANCEIRA NA ZONA DO EURO - 1998/2000 (1)

\begin{tabular}{l|r|r|r|r|r}
\hline & Mesmo país & $\begin{array}{l}\text { Outro país da } \\
\text { zona do euro }\end{array}$ & $\begin{array}{l}\text { Outro país da } \\
\text { zona do euro }\end{array}$ & Total & $\begin{array}{c}\text { Como } \\
\text { percentagem } \\
(2)\end{array}$ \\
\hline Bancos - bancos \\
\hline 1998 & 8445 & 147 & 13787 & 22379 & 13,0 \\
1999 & 41242 & 9465 & 7495 & 58202 & 34,2 \\
2000 (3) & 4528 & 11654 & 16182 & 62,0 \\
\hline Bancos - instituição não-bancária \\
\hline 1998 28604 \\
1999 & 20816 & 646 & 897 & 31147 & 37,9 \\
2000 (3) & 4768 & 1631 & 4130 & 25746 & 56,4 \\
\hline Instituição não-bancária com não-bancária & 653 & 7052 & 39,1 \\
\hline 1998 & 7299 & 7974 & 1201 & 16474 & 13,8 \\
1999 & 15508 & 378 & 21888 & 37774 & 40,7 \\
2000 (3) & 5071 & 9 & 454 & 5534 & 18,8 \\
\hline
\end{tabular}

FONTE: BIS (2000, p. 134).

NOTA: Valores em milhões de dólares.

(1) Inclui empresa, comprada ou vendida, residente na zona do euro.

(2) De fusões e aquisições em todos os países.

(3) $1 .^{\circ}$ de janeiro a 10 de abril. 
bancos para a zona do euro ${ }^{11}$ (KREGEL, 2001). De acordo com White (1998, p. 14-15), analisando as transformações nos bancos da Europa continental, nos países que fazem parte da UE "os impedimentos institucionais para competição internacional na Europa continental permanecem grandes. As estruturas legais, de impostos, regulatório e de supervisão, dentro dos quais as instituições financeiras têm que operar, continuam a diferir de forma significativa entre os vários países da União Européia. Procedimentos de contabilidade, 'padrões técnicos' e práticas de empregos diferentes também trabalham na mesma direção. Tais diferenças tornam a competição internacional mais complexa".

Uma explicação diferente - mas não excludente com a anterior para o fato de que a expansão entre fronteiras tem sido rara e a consolidação tem sido observada principalmente dentro da fronteira nacional é dada por Boot (1999, p. 610-1): "Os bancos domésticos na Europa foram - e são protegidos como bandeira nacional. Uma crença básica de que as instituições financeiras não devem ser controladas por estrangeiros tem quase que impedido qualquer fusão entre fronteiras (...) Fusões domésticas são geralmente estimuladas para proteger interesses nacionais". Na mesma direção, Belaisch et al. (2001, p. 12) colocam que "alguns comentadores têm interpretado a orientação dos governos como um aparente desejo de limitar a propriedade estrangeira de algumas instituições influentes e de criar alguns poucos 'campeões nacionais' em cada país para competir no mercado europeu e global". De fato, a consolidação tem sido limitada, algumas vezes com orientação implícita do governo, para dentro das fronteiras nacionais. Os governos dos países membros da UE têm freqüentemente recusado a entrada de bancos de (outros) países da UE. Portanto, alguns bancos que têm tentado entrar em outros países da UE têm se defrontado com forte oposição dos países hospedeiros. Em resumo, parece haver algumas barreiras que limitam a consolidação internacional de instituições financeiras dentro da Europa e inibem a criação de um mercado financeiro único na UE. Consolidação européia e mesmo consolidação envolvendo terceiros países podem ser temperados por diferenças estruturais entre os mercados de capital, impostos e regimes regulatórios de cada país (BERGER et al., 2000b).

11 De fato, como Belaisch et al. (2001, p. 56) assinalam, "a estrutura atual de supervisão bancária na zona do euro é organizada dentro das fronteiras nacionais e, como resultado da introdução do euro, o domínio geográfico da política monetária não coincide com aquele da supervisão prudencial”. 


\section{AS ESTRATÉGIAS DE EXPANSÃO DOS BANCOS MULTINACIONAIS}

O ritmo da consolidação de instituições financeiras entre países tem aumentado nos últimos anos, e, mais recentemente, tem alcançado mais amplamente o mercado bancário varejista. Para o propósito desta seção, a questão relevante é: por que os bancos sediados em determinados países estabelecem agências bancárias ou subsidiárias em países estrangeiros?

A literatura dos anos 70 e 80 (GRUBEL, 1977; ALIBER, 1984), em termos gerais, desenvolveram uma teoria da internacionalização bancária fortemente baseada na teoria de investimento direto estrangeiro na indústria. De acordo com essa explicação, os bancos multinacionais têm algumas vantagens comparativas. Bancos vão para o exterior para servir seus clientes domésticos que foram para o exterior, o que tem sido algumas vezes chamado de "efeito empuxe gravitacional" (gravitational pull effect). Os bancos multinacionais cresceram em paralelo com o investimento direto estrangeiro, uma vez que eles procuravam satisfazer a demanda por serviços das firmas multinacionais no exterior. Esse comportamento bancário de mover-se para o exterior é visto como uma atitude defensiva necessária para assegurar a continuidade dos negócios com as matrizes das subsidiárias estrangeiras, de forma que o fluxo existente de informação resultante da relação banco-cliente não seja apropriado por outro banco competidor. Secundariamente, os banco multinacionais também fazem algum negócio com outros clientes locais (famílias de alta renda, empresas de maior porte etc.), oferecendo a eles serviços especializados e informações necessárias para o comércio internacional ou para o mercado de capitais de seus países nativos.

A explicação dos motivos para um banco se expandir para o exterior pode ser interpretada em termos de preços: "O contato comercial contínuo entre o banco e a firma industrial permite ao banco ter acesso a informações sobre as condições financeiras da firma a custo mais baixo e mais rapidamente do que de qualquer outro competidor para avaliar e responder as demandas por empréstimos das firmas". Assim, "a habilidade de colher informações e os contatos pessoais entre o banco e a matriz da firma industrial em um [país estrangeiro] a custo marginal muito baixo representa a principal fonte de vantagem comparativa que a agência de um banco estrangeiro tem em lidar com a subsidiária da firma no exterior na competição com os bancos locais" (GRUBEL, 1977, p. 352-353). Dessa passagem, pode-se extrair que a 
internalização da informação é considerada a principal vantagem do banco multinacional. ${ }^{12}$ Bancos multinacionais são também considerados como capazes de desenvolver tecnologia e expertise gerencial em seu país original e então serem capazes de aplicá-los no exterior a custo marginal nulo. Esse parece ser o caso dos grandes bancos americanos que estão envolvidos na atividade bancária de atacado e negócios. A conexão com outros negócios de firmas americanas e com clientes locais relacionados a esses negócios criam a oportunidade para internalizar informação a baixo custo à la Grubel.

Historicamente, como assinalado por Focarelli e Pozzolo (2000, p. 1, itálicos adicionados), "o padrão de participação acionária do banco internacional seguiu a integração econômica entre países: os bancos estenderam suas atividades para o exterior de modo a prover serviços em transações internacionais para clientes do seu país de origem; posteriormente, com o crescente entendimento do mercado estrangeiro - em particular os aspectos institucionais e regulatórios - e o desenvolvimento de uma rede de relações com as instituições financeiras locais, alguns bancos foram induzidos a aumentar o âmbito de suas operações e prover também serviços para a população local. Embora este relato seja de modo geral preciso, (...) hoje o atual padrão de participação acionária do banco internacional depende de um conjunto maior de fatores do que somente o grau de integração econômica entre países". Em particular, a teoria de internalização de Grubel não pode ser aplicada ao segmento do mercado bancário varejista, já que a maioria dos clientes dos bancos estrangeiros, neste caso, não tem nenhuma conexão prévia com o banco estrangeiro em seu país nativo.

A recente onda de internacionalização bancária, portanto, é caracterizada não somente por instituições financeiras seguindo suas relações preexistentes, mas também (e crescentemente) por bancos globais procurando ampliar suas atividades nos mercados financeiros do país hospedeiro, principalmente por meio da aquisição de participações de controle acionário majoritário ou da aquisição de participações minoritárias, não-controladoras. ${ }^{13}$

12 Neste sentido, Casson (1990, p. 18) assinala que "quando a tecnologia leva uma firma a um novo local no exterior, o banco que tem servido a firma que está se expandindo tem uma vantagem sobre as firmas locais em servir a nova subsidiária estrangeira. Esta vantagem é em boa medida derivada do conhecimento dos requisitos do cliente e é uma vantagem monopolista que não é patentiável e que pode ser transferida para o exterior. A internalização desta vantagem transforma o banco nacional em um banco multinacional".

13 De acordo com Focarelli e Pozzolo (2000, p. 12), a determinação de "seguir o cliente" para a internacionalização bancária é somente relevante para bancos pequenos, enquanto que o comportamento de bancos maiores é determinado por políticas de diversificação bem mais complexas. 
Desse modo, a presente estratégia global dos bancos universais almeja a diversidade de suas atividades em alguns mercados financeiros, por meio de rede de agências bancárias e de maior integração no mercado local, enquanto no passado as estratégias dos bancos multinacionais visavam principalmente a servir os clientes corporativos de seu país de origem, e também dar alguma suporte para firmas domésticas para que elas pudessem acessar o mercado financeiro internacional. Essa nova estratégia tem sido, em boa medida, estimulada por uma gradual flexibilidade ou mesmo em alguns casos pela abolição das restrições legais referentes à presença de bancos multinacionais em mercados locais, tanto em países desenvolvidos quanto nos países em desenvolvimento (FREITAS, 1999).

Existem poucos trabalhos recentes que procuram estabelecer um padrão de expansão para a recente onda de internacionalização bancária. ${ }^{14}$ Uma das mais comuns explicações, como já visto anteriormente, está relacionada aos efeitos de um aumento na competição bancária causada pela desregulamentação financeira. Como margens e tarifas estão apertadas na área de serviços bancários domésticos, as firmas financeiras buscam expandirse para o exterior para poderem obter mais altos retornos. Assim, com as margens líquidas de juros dos bancos sob pressão, devido ao aumento na competição bancária, e como as grandes instituições financeiras estão de forma geral estabelecidas em economias maduras, com potencial baixo de expansão, alguns bancos estão procurando diversificar geograficamente suas atividades para mercados com potencial de crescimento e/ou com maiores margens líquidas de juros. De modo geral, a internacionalização bancária resulta da tendência de aumento na escala mínima necessária para o banco permanecer competitivo de modo a aprimorar sua habilidade de gerar lucros. Uma outra explicação é a de que existem ganhos potenciais de redução de risco como resultado da diversificação de receitas dos múltiplos produtos, de grupos de clientes e regiões geográficas na organização de serviços financeiros múltiplos, e esses ganhos aumentam com o número de atividades desenvolvidas.

De forma geral, a evidência empírica na literatura (DEMINGUÇ-KUNT e HUIZINGA, 1998; CLAESSENS et al., 1998) mostra que instituições estrangeiras financeiras são menos eficientes do que as instituições domésticas, ao menos nos países desenvolvidos. Para analisar essa constatação, Berger et al. (2000b) consideraram duas hipóteses:

14 Existem algumas poucas exceções. Ver, por exemplo, Berger et al. (2000b) e Focarelli e Pozzolo (2000). 
(a) hipótese da vantagem doméstica: (home field advantage hypothesis), sob o qual as instituições domésticas são em geral mais eficientes do que as instituições de nações estrangeiras; a vantagem é, em parte, devido a diseconomias organizacionais para operar (por exemplo, conflito entre equipes de trabalho de diferentes países) ou monitorar (pode ser difícil avaliar o comportamento e esforço de gerentes em mercados distantes) uma instituição a distância, ou em parte por causa de outras barreiras - incluindo diferenças no idioma, cultura, moeda, estruturas regulatórias e de supervisão - ou ainda de barreiras implícitas contra instituições estrangeiras;

(b) hipótese da vantagem global (global advantage hypothesis), sob o qual algumas instituições estrangeiras administradas de forma eficiente são capazes de superar as desvantagens de cruzar fronteiras e de operar de forma mais eficiente do que as instituições domésticas, já que elas possuem uma maior eficiência quando operam em outras nações em função da difusão de suas habilidades gerenciais superiores ou de políticas e procedimentos da melhor prática sobre mais recursos, da diminuição nos custos de operação ou ainda da diversificação de riscos que permitem que elas obtenham mais altos retornos esperados em seus investimentos. ${ }^{15}$

Testando essas hipóteses em cinco países (França, Alemanha, Espanha, Reino Unido e EUA) durante os anos 90, Berger et al. (2000b) mostram evidências em favor de uma limitada forma da hipótese da vantagem global em que somente as instituições eficientes em um ou limitado número de países com mercados específicos ou condições regulatórias favoráveis em seus países de origem podem operar de forma mais eficiente do que as instituições domésticas. Esse achado também sugere que algumas organizações bancárias

15 Williams (1997) denomina a última hipótese como "teoria eclética”, que diz que os bancos multinacionais devem ter alguma vantagem monopólica para superar a vantagem natural das instituições locais. Essa vantagem é desenvolvida domesticamente pelo banco multinacional e então aplicada no exterior. Seguindo a teoria de HymerKindelberger, as vantagens naturais das instituições locais sobre qualquer instituição estrangeira que queira entrar são devido a: (i) o conhecimento das preferências do consumidor e das características institucionais; e, (ii) os custos associados com a distância da matriz, incluindo custos de comunicação, tempo de viagem e distância em lidar com erros (WILLIAMS, 1997, p. 92). 
podem operar em países estrangeiros em nível acima dos graus de eficiência dos bancos domésticos, pavimentando o caminho para alguma consolidação adicional. Um estudo econométrico feito por Focarelli e Pozzolo (2000) mostra, nesta mesma direção, que os bancos com participações em outras nações são em geral maiores e têm suas matrizes em países com um mercado financeiro mais desenvolvido e eficiente. Bancos operando em países onde o setor bancário é maior e mais lucrativo devem ser capazes de exportar habilidades superiores e são, portanto, mais prováveis de expandirem suas atividades para o exterior. Em particular, as oportunidades locais do mercado - que combina mais altas taxas de crescimento econômico, condições econômicas mais estáveis e ineficiência bancária no país de destino - são os principais determinantes nas decisões dos bancos relacionadas à expansão para o exterior.

Bancos preferem investir em países onde esperam que os lucros sejam maiores, devido ao crescimento econômico esperado mais elevado e à perspectiva de reduzir a ineficiência frente aos bancos locais. As oportunidades de lucro no mercado hospedeiro têm-se tornado um fator-chave na determinação do padrão de participações acionárias dos bancos estrangeiros, que incluem as mais variadas formas de participação, tais como aquisição plena, compras de atividades específicas, joint-ventures ou alianças com bancos locais etc. Concluindo, F\&As internacionais podem ser induzidas pelo desejo da instituição em aumentar a eficiência (custos ou rendimentos) ou em obter efeitos da redução de riscos derivados da diversificação. Entretanto, como Berger (2000b, p. 7) reconhece, "existe muito pouca pesquisa sobre os determinantes da consolidação entre países que poderia dar informação de como os bancos melhoram suas posições de risco e sua eficiência”.

\section{ESTRATÉGIA DE EXPANSÃO DOS BANCOS EUROPEUS NA AMÉRICA LATINA E BRASIL}

\section{1. Determinantes das estratégias de expansão dos bancos europeus na América Latina e Brasil}

Da última seção pode ser extraído que, tanto do ponto de vista histórico quanto do ponto de vista teórico-analítico, existem fortes razões para se acreditar que está em operação, em boa medida como um fenômeno internacional, um processo de consolidação na indústria bancária, como resultado da desregulamentação financeira e das mudanças tecnológicas. A 
nova fase de internacionalização bancária é uma conseqüência deste processo, em que, de forma crescente, as instituições financeiras buscam diversificar suas atividades, tanto em termos de produtos e serviços quanto geograficamente. Entretanto, deve ser reconhecido que nem todos os grandes bancos no mundo aspiram a se tornar multinacionais. De fato, existem exemplos de bancos bem-sucedidos, tais como o britânico Lloyds TSB, que têm escolhido não perseguir uma agressiva estratégia de expansão internacional, mas pelo contrário, buscam centrar seu foco em negócios no mercado varejista doméstico (mercado de hipoteca, banco pessoal, seguro de vida, etc.).

Crises bancárias, desregulamentação e globalização de serviços bancários têm levado a um aumento significativo na presença de bancos estrangeiros em economias emergentes na segunda metade dos anos $90 .{ }^{16}$ Desse modo, o processo de consolidação bancária tem se acelerado na indústria bancária nas economias emergentes, transformando uma indústria que era tradicionalmente muito protegida. Nesta direção, Hawkins e Mihaljek (2001, p. 3) assinalam que "mercado global e desenvolvimentos tecnológicos, pressões macroeconômicas e crises bancárias nos anos 90 têm forçado a indústria bancária e os reguladores a mudar sua velha forma de fazerem negócios e a desregulamentar esta indústria a nível nacional e a abrir os mercados financeiros para a competição estrangeira. (...) Essas mudanças têm aumentado significativamente as pressões competitivas sobre os bancos nas economias emergentes e têm levado a profundas mudanças na estrutura da indústria bancária”.

América Latina é uma das regiões que recebeu um dos maiores fluxos de investimento direto estrangeiro (IDE) no setor bancário no mundo durante a década de 90. Entretanto, não se pode entender a onda de IDE no setor bancário na região isolada de um movimento geral de IDE para a América Latina durante os anos 90. De fato, América Latina e Caribe receberam níveis recordes de IDE nos anos 90, com os fluxos de investimento totalizando US\$ 76,7 bilhões somente em 1998. Essa quantia correspondeu a cerca de $41 \%$ do fluxo total de FDI para países em desenvolvimento no ano. Por outro lado, 42\% do fluxo de FDI para América Latina em 1998 foi canalizado para um único país - Brasil - que, desde 1996, tem liderado o fluxo de IDE na América

16 De acordo com Hawkins e Mihaljek (2001, p. 24), na Europa central a participação dos bancos estrangeiros em termos do total de ativos e de capital é ao redor de dois terços ou mais, o que faz com que os sistemas bancários desses países se situem entre os mais abertos no mundo, enquanto que na América Latina, o market share dos bancos estrangeiros aumentou de uma média de 7\% no início dos anos 90 para 40\% no ano 2000. 
Latina e tem sido o segundo maior receptor entre os países em desenvolvimento (CEPAL, 2000, p. 35-36). ${ }^{17}$

Alguns dos principais determinantes da expansão de bancos europeus na América Latina podem ser sumariados da seguinte forma:

- o processo de reestruturação do setor bancário no contexto da união econômica e monetária européia, como discutido no Capítulo 2. A expansão para o exterior para alguns bancos europeus não é somente uma fonte de diversificação de ganhos mas também uma forma que eles têm encontrado para fortalecer sua posição no mercado bancário europeu, considerando o aumento na competição bancária na Área Econômica Européia. A estratégia dos bancos europeus para a América Latina pode ser interpretada como uma resposta para este ambiente mais competitivo, em que vários fatores estão erodindo as receitas no tradicional negócio bancário. Ademais, devido a restrições regulatórias e políticas, existem alguns impedimentos para F\&As dentro dos países do UE e incentivo para tal atividade fora do bloco. A preferência pela América Latina e, em menor grau pela Europa central, é devido em parte ao fato de que o sudeste asiático durante a segunda metade dos anos 90 estava em crise, e a Índia e China têm seus sistemas financeiros bastante fechados para bancos estrangeiros, de forma que os principais mercados emergentes que se abriram foram Argentina, Brasil e México;

- em particular, a dinâmica da internacionalização dos bancos espanhóis, uma vez que eles têm sido os principais protagonistas na recente onda de bancos estrangeiros na América Latina. Esses bancos perseguiram estratégias de crescimento baseadas em F\&As em seu mercado doméstico antes deles se lançarem em

17 Durante os anos 90, como resultado da implementação de políticas que objetivavam a estabilização de preços da economia (Plano Real), do amplo processo de liberalização que tem aberto atividades que eram até então restritas a investidores estrangeiros, das políticas de integração regional e de um vasto programa de privatizações, os fluxos líquidos de IDE para o Brasil cresceram de cerca de US\$ 2 bilhões no período 1990/1994 para US\$ 30 bilhões nos últimos dois anos da década. (CEPAL, 2001, p. 25). 
uma estratégia de expansão internacional. ${ }^{18}$ Assim, eles já tinham alcançado um estágio de bancos "maduros" quando decidiram expandir-se para o exterior. De fato, com a implementação da UME e a perspectiva de introdução do euro, os maiores bancos espanhóis - em particular, Banco Bilbao Vizcaya (BBv), Banco Santander e Banco Central Hispanico (BCH) -, de modo a manter sua posição competitiva e defenderse da ameaça de apostas hostis por parte de competidores locais e estrangeiros, tiveram que olhar para além de sua fronteira natural na busca de mercados globais. Em um estágio inicial desse processo, observou-se uma proliferação de alianças e acordos cooperativos com outras instituições financeiras, principalmente dentro da União Européia, enquanto que a segunda fase tem envolvido, em ritmo mais rápido, uma estratégia agressiva de expansão visando aos principais mercados latino-americanos (CEPAL, 2000, p. 159). Uma vez que durante os anos 90 muitos bancos europeus, incluindo bancos da Holanda e Alemanha, estiveram ocupados com a expansão para Europa central e do leste, enquanto que os bancos americanos estavam ocupados com F\&As em seu próprio mercado doméstico, o mercado natural para os bancos espanhóis foi a América Latina, devido, inclusive, aos laços culturais existentes;

- o processo de desregulamentação nos países da América Latina no amplo contexto das reformas econômicas e políticas que tem ocorrido desde o início dos anos 90, e que tem permitido a entrada de empresas estrangeiras em setores econômicoschave, tais como setor bancário, telecomunicações e "utilities". Os programas de privatização foram, em geral, parte das reformas de longo prazo no setor público, que envolveu a privatização de grandes empresas estatais com o objetivo de

18 A expansão de bancos espanhóis na América Latina deve também ser vista no contexto mais amplo em que, depois de um período de mudanças estruturais na economia espanhola, determinado parcialmente pelo processo de privatização de empresas estatais, as maiores firmas espanholas de serviço (transporte, telecomunicações, energia e serviços financeiros) decidiram expandir-se para o exterior. Desde 1994 a América Latina tem sido o principal destino dos investimentos dessas firmas, com o total de investimentos espanhóis pulando de US\$ 4,5 bilhões em 1990 para mais de US\$ 18,5 bilhões em 1998 (CEPAL, 2000, p. 33). 
consolidar as finanças públicas e diminuir a dívida pública interna. Além disso, o aprofundamento do papel do mercado e do setor privado foi também um dos motivos da reforma (HAWKINS e MILALJEK, 2001, p. 13);

- as avaliações do patrimônio das empresas latino-americanas, incluindo bancos, são muito mais baratas do que das empresas européias, tornando mais fácil obter uma grande fatia do mercado a um custo mais baixo. De acordo com Sebastian e Hernansanz (2000, p. 19), 1\% de participação no mercado de depósitos bancários na Alemanha em 1999 custava US\$ 2,3 bilhões se isto for alcançado pela compra de participação nos maiores bancos listados ${ }^{19}$. A mesma participação teria representado um desembolso de US\$ 196 milhões na Argentina e US\$ 205 milhões no México;

- o potencial de crescimento do mercado bancário na América Latina é muito maior do que na Europa, que tem um mercado bancário maduro. $\mathrm{O}$ tamanho do sistema financeiro em termos da razão M3/GDP é somente 28\% na América Latina, enquanto que na zona do euro ela é $77 \%$ e nos EUA, $71 \%$ (SEBASTIAN e HERNANSANZ, 2000, p. 18);

- O setor bancário latino-americano oferece melhores perspectivas para retornos crescentes para instituições financeiras, uma vez que as margens de intermediação com que os bancos operam nesses países são consideravelmente mais altas do que no mundo desenvolvido. Enquanto que a margem média sobre os ativos (receitas líquidas de juros sobre o total de ativos) dos bancos domésticos na América Latina era de 5,8\% para o período 1988/95 (no Brasil era 6,6\% e na Argentina $9,9 \%$ ), nos países da oCDE ela era $2,8 \%$ para o mesmo período (ClAessens et al., 1998, p. 26). Por outro lado, os bancos latinoamericanos aumentaram firmemente sua já elevada lucratividade durante os anos 90, embora as receitas líquidas de juros tenham sido estáveis. Sua lucratividade é alta tanto em comparação aos países do G3 quanto aos outros países emergentes (ver tabela 3);

19 A lista dos maiores bancos alemães listados inclui: Deutsche Bank, Bayerische Hypo und Verisnsbank, Dresdner Bank, Commerzabank, e Bankgesellschaft Berlin. 
- os ganhos potenciais em eficiência é alto na América Latina, uma vez que o grau de eficiência bancária na região é de forma geral mais baixo do que dos países desenvolvidos. De fato, a razão despesas operacionais/total dos ativos dos bancos domésticos na América Latina foi em média 5,5\% em 1992/ 1997, enquanto esta relação foi 1,7\% nos países do G3 (EUA, Japão e Alemanha), 1,6\% na Ásia oriental e 4,1\% na Europa central, no mesmo período (ver tabela 3 ). O elevado custo operacional (assim como os altos spreads) dos bancos domésticos na América Latina é, em grande medida, o legado do período de alta inflação dos anos 80 e início dos anos 90, quando as receitas inflacionárias geravam lucros fáceis para os bancos e, conseqüentemente, havia pouca pressão para cortar custos.

Como visto na seção anterior, os principais determinantes da decisão de um banco se expandir para o exterior são as oportunidades do mercado local, referentes às mais altas taxas esperadas de crescimento econômico, às condições econômicas mais estáveis e à ineficiência dos bancos no país hospedeiro. De fato, no caso do Brasil, os determinantes internos da recente penetração dos bancos estrangeiros estão relacionados principalmente às condições econômicas mais estáveis, a partir do processo de estabilização de preços desde 1994 - que alterou o panorama de negócios de mais longo prazo no Brasil -, às maiores taxas esperadas de crescimento econômico e ao potencial de crescimento do mercado bancário. Além disso, desde o início dos anos 90, a economia brasileira vem passando por um vasto processo de liberalização que tem flexibilizado atividades que eram anteriormente restritivas para investidores estrangeiros. Nesse contexto, a recente entrada de bancos estrangeiros está relacionada à gradual flexibilidade nas restrições legais referentes à presença de bancos estrangeiros no setor bancário brasileiro. De acordo com o Artigo 52 das Disposições Transitórias da Constituição de 1988, é proibido, até ser regulamentado por lei complementar, a instalação de novas agências por parte de instituições financeiras estrangeiras e o aumento da participação no capital de instituições financeiras baseadas no país. Entretanto, a Constituição de 1988 manteve aberta uma possibilidade de as instituições estrangeiras terem acesso ao mercado doméstico, já que o artigo 52 também estabeleceu que tais restrições não se aplicam a autorizações resultantes de acordos internacionais, reciprocidade ou decisões tomadas no interesse do governo brasileiro.

Uma importante mudança ocorreu em 1995, no contexto da crise bancária, que resultou da adoção de uma política monetária restritiva e do aumento da taxa de juros a patamares elevadíssimos face aos efeitos da crise 
PAULA, L. F. de. Determinantes e impactos da recente entrada de bancos...

Tabela 3 - DESEMPENHO DO SETOR BANCÁRIO EM VÁRIAS REGIÕES - 1992/99 (COMO PERCENTAGEM DO TOTAL DE ATIVOS)

\begin{tabular}{|c|c|c|c|c|c|c|c|c|c|c|c|c|}
\hline & \multicolumn{3}{|c|}{ Asia oriental ${ }^{*}$} & \multicolumn{3}{|c|}{ América Latina ${ }^{\star \star}$} & \multicolumn{3}{|c|}{ Europa central $\left.\right|^{\star \star \star}$} & \multicolumn{3}{|c|}{$\mathrm{G} 3^{\star \star \star \star \star}$} \\
\hline & $\begin{array}{c}1992- \\
97\end{array}$ & 1998 & 1999 & $\begin{array}{c}1992- \\
97\end{array}$ & 1998 & 1999 & $\begin{array}{c}1992- \\
97\end{array}$ & 1998 & 1999 & $\begin{array}{c}1992- \\
97\end{array}$ & 1998 & 1999 \\
\hline $\begin{array}{l}\text { Receitas líquidas } \\
\text { de juros }\end{array}$ & 2,6 & 1,8 & 2,2 & 5,2 & 5,3 & 5,4 & 3,1 & 2,8 & 2,5 & 2,0 & 1,8 & 2,0 \\
\hline $\begin{array}{l}\text { Outras } \\
\text { receitas }\end{array}$ & 0.7 & 1,2 & 08 & 23 & 20 & 18 & 23 & 21 & 20 & 07 & 08 & 10 \\
\hline Despesas & & & & & & & & & & & & \\
\hline $\begin{array}{l}\text { operacionais } \\
\text { Empréstimos em }\end{array}$ & 1,6 & 2,4 & 2,3 & 5,5 & 5,5 & 5,7 & 4,1 & 3,5 & 3,1 & 1,7 & 1,6 & 1,8 \\
\hline atraso & 0,6 & 6,3 & 1,8 & 1,2 & 1,1 & 1,7 & 0,6 & 0,6 & 0,4 & 0,2 & 0,4 & 0,3 \\
\hline $\begin{array}{l}\text { Lucros antes dos } \\
\text { impostos }\end{array}$ & 0,8 & $-5,5$ & $-0,7$ & 1,4 & 1,3 & 2,4 & 0,5 & 0,7 & 1,0 & 0,7 & 0,6 & 0,8 \\
\hline
\end{tabular}

FONTE: Hawkins e Mihaljek (2001, p. 6).

* Média simples da Indonésia, Coréia, Malásia, Filipinas e Tailândia.

** Média simples da Argentina, Brasil, Chile, Colômbia, México e Peru.

*** Média simples da República Checa, Hungria e Polônia.

***** Média simples da Alemanha, Estados Unidos e Japão.

mexicana de 1994/1995. De acordo com Carvalho (2000, p. 148), "a crise bancária de 1995 abriu uma janela de oportunidade para os bancos estrangeiros colocarem um pé no país. A crise desvalorizou os bancos existentes, colocando um grande número deles sob o controle do Banco Central, sem comprometer as possibilidades de longo prazo da indústria. Em um relatório datado de dezembro de 1998, o Banco Central do Brasil identificou 104 instituições financeiras como passando por alguma espécie de 'ajustamento' entre o lançamento do Plano Real e aquela data".

O recente processo de consolidação bancária no Brasil é de alguma forma similar à experiência mexicana no sentido que em ambos países as autoridades governamentais responderam à crise bancária com uma série de programas de suporte para instituições financeiras e seus tomadores. Esses programas pretendiam reforçar a saúde do setor financeiro e, ao mesmo tempo, abrir o setor para os bancos estrangeiros, uma vez que a presença desses bancos poderia ajudar a fortalecer a saúde do setor. ${ }^{20}$ Além disso, em contexto de

20 No caso brasileiro, o governo federal lançou, em novembro de 1995, o Programa de Estímulo à Reestruturação e ao Fortalecimento do Sistema Financeiro Nacional, o PROER, que financiou as aquisições de sete bancos, de acordo com um relatório sobre bancos brasileiros (Gazeta Mercantil, 16/09/1999): Nacional pelo Unibanco (banco brasileiro); Econômico pelo Excel (brasileiro); Mercantil de Pernambuco pelo Banco Rural (brasileiro); Banco Antonio de Queiroz pelo Banco United (brasileiro); Banorte pelo Bandeirantes (brasileiro); Banco Martinelli pelo Pontual (brasileiro); Bamerindus pelo HSBC (britânico). 
desregulamentação financeira, a entrada de bancos estrangeiros tem sido usada como uma política para enfraquecer os monopólios locais, que tinham sido estabelecidos sob a estrutura regulatória anterior.

Nesse contexto, a entrada de alguns bancos estrangeiros foi permitida pelo governo brasileiro de modo a viabilizar a compra de alguns bancos problemáticos - tais como Banco Excel-Econômico e Banco Bamerindus - e também fortalecer o setor bancário nacional. A Exposição de Motivos n. 311, de 23/08/1995, um ato de autoria do Ministério da Fazenda e aprovado pelo Presidente da República, permitiu ao Presidente autorizar excepcionalmente, caso a caso, a entrada de bancos estrangeiros no Brasil. Naquela ocasião, o governo brasileiro anunciou que não seria permitido aos bancos estrangeiros abrirem novas agências bancárias ou adquirirem bancos menores, a menos que eles comprassem alguns dos problemáticos bancos brasileiros. A entrada de bancos estrangeiros foi aprovada caso a caso, principalmente para recapitalizar os bancos problemáticos. Essa norma presidencial diz que a entrada dos bancos estrangeiros é do interesse do país, e enfatiza os seguintes aspectos favoráveis:

- o aprimoramento na eficiência operacional do setor bancário com efeitos positivos sobre a intermediação financeira;

- o aumento na competição bancária causaria uma redução nos spreads e nas tarifas bancárias, com impactos positivos sobre a taxa de juros dos empréstimos;

- a melhor e mais diversificada oferta de serviços bancários a mais baixo custo;

- a introdução de novas tecnologias de gerenciamento e de inovações de produtos e serviços.

Como resultado de uma maior flexibilidade na estrutura regulatória referente à entrada de bancos estrangeiros, o governo brasileiro tem permitido a entrada de um grande número de bancos estrangeiros no mercado bancário doméstico, indo ao encontro da tendência internacional de expansão dos conglomerados financeiros, que estão procurando novos mercados para seus negócios. Um outro fator que tem atraído bancos estrangeiros para o Brasil tem sido o programa de privatização de bancos públicos, conhecido como Proes. ${ }^{21}$

21 O Programa de Incentivo à Redução do Setor Público Estadual na Atividade Bancária (Proes) foi lançado em agosto de 1996 pela Medida Provisória 1.514. O Proes forma parte de um processo amplo de ajuste fiscal dos Estados e de reestruturação da dívida pública. Sob os arranjos do Proes, o governo federal financia a reestruturação dos bancos estaduais. 
Como Hawkins e Mihaljek (2001, p. 13) colocam, "quando o programa para reestruturação dos bancos públicos estiver completo em cerca de dois anos, somente seis bancos é esperado permanecer em mãos estatais, comparados com 30 bancos em meados de 1996. A velocidade desta mudança tem sido atribuída ao compromisso do governo federal de financiar todos os custos de reestruturação, garantido que os bancos públicos são privatizados, convertidos em agências de desenvolvimento, ou liquidados”.

As mudanças na estrutura regulatória referente a bancos estrangeiros, o programa de privatização de bancos estaduais, a estabilização de preços a partir de 1994, o crescente potencial do mercado bancário varejista brasileiro, o desenvolvimento - ainda infante - dos fundos de pensão e mercado de títulos no Brasil, a crescente integração da economia brasileira no fluxo comercial e financeiro, todos esses fatores juntos têm atraído o capital estrangeiro para o setor bancário brasileiro. É interessante notar que os bancos europeus lideraram as principais aquisições bancárias envolvendo bancos estrangeiros durante os anos 90, o que sugere que a onda de aquisições e fusões bancárias no Brasil está de alguma forma relacionada às mudanças no sistema financeiro europeu no contexto da unificação econômica e monetária.

\subsection{A recente onda de bancos europeus no Brasil: um quadro}

A recente onda de fusões e aquisições no setor bancário no Brasil envolveu, inicialmente, a compra de bancos com problemas por bancos saudáveis, como tipicamente são os casos da aquisição do Nacional pelo Unibanco, do Econômico pelo Excel e do Bamerindus pelo HSBC. Ademais, e crescentemente, o controle de bancos envolveu bancos compradores mais fortes e, algumas vezes, um alvo fraco, mas não insolvente, tais como a compra do BCN pelo Bradesco, do Noroeste pelo Santander, e do Real pelo ABNAmro. A tabela 4 mostra as F\&As que foram feitas no setor bancário brasileiro durante o período 1995/2000. A partir da tabela pode ser extraído que:

a) os bancos estrangeiros comandaram inicialmente as aquisições, com a clara predominância de bancos europeus. De forma diferente da Argentina, onde as aquisições estrangeiras incluíram dois dos três maiores bancos privados, as aquisições estrangeiras no Brasil têm envolvido principalmente bancos de tamanho médio. Isso reflete parcialmente o fato de que a capitalização de mercado dos maiores bancos brasileiros torna a compra destes proibitivos; 
b) as principais aquisições estrangeiras foram a compra do Bamerindus pelo HSBC, que foi paradigmática, uma vez que envolveu pela primeira vez um grande banco varejista, o Excel/ Econômico pelo BBva, o América do Sul pelo Sudameris, o Banco Noroeste pelo Santander, o Banco Real pelo ABN-Amro, e o Banespa pelo BSCH. ${ }^{22}$ Esta última compra foi a maior aquisição feita nos últimos anos no Brasil, pois envolveu a compra de um banco com ativos no total de cerca de US\$16,0 bilhões. Essa aquisição permitiu que o Banco Santander do Brasil pulasse alguns degraus no ranking dos bancos, tornandose o terceiro maior banco privado no Brasil e o quinto maior no ranking geral dos bancos, incluindo bancos públicos. $\mathrm{O}$ Banespa tem uma forte rede de varejo, principalmente no Estado de São Paulo, o mais rico Estado brasileiro. Sua compra representou uma espécie de "ponto de mutação" na história do BSCH no Brasil, uma vez que, antes da aquisição do Banespa em novembro de 2000, os investimentos relativamente modestos do Banco Santander do Brasil no Meridional e no prestigioso banco de investimento Bozano, Simonsen deixou o grupo, ainda fora da elite do mercado, como o número $7 \mathrm{da}$ indústria bancária; ${ }^{23}$

c) os grandes bancos americanos já estabelecidos no Brasil Citibank e BankBoston - não têm participado da onda de F\&As, e optaram por crescer organicamente no mercado bancário brasileiro, onde eles tradicionalmente têm focado suas atividades em uma clientela menor e mais seletiva. ${ }^{24} \mathrm{~A}$ estratégia mais recente desses bancos no Brasil tem sido ampliar sua base de clientes, incluindo segmentos da classe média e firmas de tamanho médio. BankBoston tem procurado atuar em um

22 Santander também adquiriu o Banco Geral do Comércio (1997) e o Grupo Meridional (2000), enquanto que o ABN-Amro comprou o Banco do Estado de Pernambuco (1998), que tinha uma presença importante na região Nordeste do país.

23 O grupo financeiro Meridional, que incluía o Banco Meridional e Bozano, Simonsen, foi comprado pelo BSCH por cerca de US\$ 1 bilhão, enquanto que o Banespa foi comprado por US\$ 3,7 bilhões, uma soma cinco vezes maior do que o seu valor registrado.

24 As recentes aquisições do BankBoston e, principalmente, do Citibank de bancos locais ou agências bancárias na América Latina sugerem que a estratégia destes bancos pode estar de alguma forma mudando. 
segmento mais seletivo do mercado varejista, com renda mensal acima de $\mathrm{R} \$ 4.000,00$, enquanto que o Citibank tem procurado ampliar sua base de clientes, procurando incluir em sua clientela segmentos inferiores da classe média, com renda mensal acima de $\mathrm{R} \$ 1.000,00$, assim como firmas com receitas anuais acima de $\mathrm{R} \$ 5$ milhões. A tímida presença de bancos americanos na recente onda de F\&As no Brasil pode ser parcialmente explicada pelo fato de que eles têm obtido uma boa lucratividade com a oferta de novos produtos em seu próprio mercado doméstico (Estados Unidos), onde eles têm sido capazes de expandir-se geograficamente, devido à desregulamentação do sistema financeiro. Conseqüentemente, a estratégia de diversificação geográfica para o exterior, em particular para América Latina, tornou-se secundária para a estratégia global dos bancos americanos, com a possível exceção do México, uma economia que tem uma forte ligação com a economia americana (NAFTA), na qual o Citibank comprou recentemente o grupo financeiro Banamex-Accival ("Banacci") e obteve a liderança no setor bancário mexicano;

d) os três maiores bancos privados domésticos - Bradesco, Itaú e Unibanco - têm reagido à penetração dos bancos estrangeiros, participando ativamente do processo de fusões e aquisições, com algumas importantes compras, tais como o banco Nacional pelo Unibanco, о вСN/Credireal pelo Bradesco, о Banerj pelo Itaú e o Bandeirantes pelo Unibanco. Particularmente importante tem sido a participação do Itaú na aquisição dos bancos estaduais, tais como Banestado (Paraná), Banerj (Rio) e Bemge (Minas Gerais). Nos casos do Itaú, e principalmente do Unibanco - com um tamanho menor que Bradesco, que é o maior banco privado brasileiro -, seus comportamentos pareceram em parte tomar a forma de uma reação defensiva, já que eles procuram manter seu market share e liderança no mercado bancário usando aquisições e fusões de modo a evitar a ameaça de serem comprados por outros bancos.

A crescente presença de bancos estrangeiros no Brasil é confirmada pelos dados disponíveis. Em termos do market share no setor bancário, os bancos controlados por grupos financeiros estrangeiros têm elevado sua participação de 7,2\% em 1994, 12,8\% em 1997 para 27,4\% em 2000, no total dos ativos do setor bancário em somente seis anos, enquanto que declina a 
PAULA, L. F. de. Determinantes e impactos da recente entrada de bancos...

Tabela 4 - PRINCIPAIS F\&AS NO SETOR BANCÁRIO BRASILEIRO - 1995/2000

\begin{tabular}{|c|c|c|c|}
\hline Ano & Adquirente & Origem do adquirente & Instituição adquirida \\
\hline 2000 & $\begin{array}{l}\text { BSCH } \\
\text { Itaú } \\
\text { Bradesco } \\
\text { Unibanco } \\
\text { BSCH } \\
\end{array}$ & $\begin{array}{l}\text { Espanha } \\
\text { Brasil } \\
\text { Brasil } \\
\text { Brasil } \\
\text { Espanha } \\
\end{array}$ & $\begin{array}{l}\text { Banespa } \\
\text { Banestado } \\
\text { Boavista } \\
\text { Bandeirantes/Credibanco } \\
\text { Meridional/Bozano Simonsen }\end{array}$ \\
\hline 1999 & $\begin{array}{l}\text { Bradesco } \\
\text { Bradesco/BCN }\end{array}$ & $\begin{array}{l}\text { Brasil } \\
\text { Brasil } \\
\end{array}$ & $\begin{array}{l}\text { Banco do Estado da Bahia (Baneb) } \\
\text { Pontual }\end{array}$ \\
\hline 1998 & $\begin{array}{l}\text { ABN-Amro } \\
\text { ABN-Amro } \\
\text { Itaú } \\
\text { Unibanco } \\
\text { Sudameris (Intesa/Crédit Agricole) } \\
\text { Chase Manhattan } \\
\text { Bradesco } \\
\text { GE Capital } \\
\text { CSFB } \\
\text { BBVA } \\
\text { Caixa Geral de Depósitos }\end{array}$ & $\begin{array}{l}\text { Países Baixos } \\
\text { Países Baixos } \\
\text { Brasil } \\
\text { Brasil } \\
\text { Itália/França/Brasil } \\
\text { Estados Unidos } \\
\text { Brasil } \\
\text { Estados Unidos } \\
\text { Suíça } \\
\text { Espanha } \\
\text { Portugal }\end{array}$ & $\begin{array}{l}\text { Banco Real } \\
\text { Banco do Estado de Pernambuco } \\
\text { Bemge } \\
\text { Dibens } \\
\text { América do Sul } \\
\text { Patrimônio } \\
\text { Pontual } \\
\text { Banco Mappin } \\
\text { Banco Garantia } \\
\text { Excel-Econômico } \\
\text { Bandeirantes }\end{array}$ \\
\hline 1997 & $\begin{array}{l}\text { Santander } \\
\text { Banco Interatlantico } \\
\text { Santander } \\
\text { Itaú } \\
\text { Bradesco } \\
\text { HSBC } \\
\text { Bozano Simonsen } \\
\text { Swiss Bank Corporation } \\
\text { Robert Fleming } \\
\text { NationsBank } \\
\text { American Express } \\
\text { Banco de Crédito Nacional (BCN) } \\
\text { Mellon Bank } \\
\text { Llyods } \\
\text { Unibanco } \\
\text { Icatú }\end{array}$ & $\begin{array}{l}\text { Espanha } \\
\text { Portugal/França } \\
\text { Espanha } \\
\text { Brasil } \\
\text { Brasil } \\
\text { Reino Unido } \\
\text { Brasil } \\
\text { Suíça } \\
\text { Reino Unido } \\
\text { Estados Unidos } \\
\text { Estados Unidos } \\
\text { Brasil } \\
\text { Estados Unidos } \\
\text { Reino Unido } \\
\text { Brasil } \\
\text { Brasil }\end{array}$ & $\begin{array}{l}\text { Banco Noroeste } \\
\text { Boavista } \\
\text { Banco Geral de Comércio } \\
\text { Banerj } \\
\text { BCN/Credireal } \\
\text { Bamerindus } \\
\text { Meridional } \\
\text { Omega } \\
\text { Graphus } \\
\text { Liberal } \\
\text { SRL } \\
\text { Credireal } \\
\text { Brascan } \\
\text { Multiplic/Losango } \\
\text { Fininvest (50\%) } \\
\text { Fininvest (50\%) } \\
\end{array}$ \\
\hline 1996 & $\begin{array}{l}\text { Banco de Crédito Nacional } \\
\text { Cindam } \\
\text { Banque Nacional de Paris } \\
\text { BBA Creditanstalt } \\
\text { Itaú } \\
\text { Itamarati } \\
\text { Excel } \\
\text { Sudameris Brasil }\end{array}$ & $\begin{array}{l}\text { Brasil } \\
\text { Brasil } \\
\text { França } \\
\text { Brasil/Áustria } \\
\text { Brasil } \\
\text { Brasil } \\
\text { Brasil } \\
\text { Itália/França/Brasil } \\
\end{array}$ & $\begin{array}{l}\text { Itamarati } \\
\text { Fonte } \\
\text { Banco Comercial de São Paulo } \\
\text { Financiadora Mappin } \\
\text { Banco Francês e Brasileiro } \\
\text { Crefisul } \\
\text { Econômico } \\
\text { Financeiro\&Industrial de Investimento }\end{array}$ \\
\hline 1995 & $\begin{array}{l}\text { Unibanco } \\
\text { Pontual }\end{array}$ & $\begin{array}{l}\text { Brasil } \\
\text { Brasil } \\
\end{array}$ & $\begin{array}{l}\text { Nacional } \\
\text { Digibanco }\end{array}$ \\
\hline
\end{tabular}

FONTE: Elaboração do autor com informações do Chase Manhattan (2000) e do Banco Central do Brasil. 
PAULA, L. F. de. Determinantes e impactos da recente entrada de bancos...

Tabela 5 - MARKET SHARE DO SETOR BANCÁRIO NO BRASIL (TOTAL DE ATIVOS) $-1993 / 2000(\%)$

\begin{tabular}{l|c|c|c|c|c|c|c|c}
\hline \hline Instituição & 1993 & 1994 & 1995 & 1996 & 1997 & 1998 & 1999 & 2000 \\
\hline \hline $\begin{array}{l}\text { Bancos com controle } \\
\text { estrangeiro }\end{array}$ & 8,4 & 7,2 & 8,4 & 9,8 & 12,8 & 18,4 & 23,2 & 27,4 \\
\hline $\begin{array}{l}\text { Bancos domésticos } \\
\text { privados }\end{array}$ & 40,7 & 41,2 & 39,2 & 39,0 & 36,8 & 35,3 & 33,1 & 35,2 \\
$\begin{array}{l}\text { Bancos públicos } \\
\text { (+ caixas estaduais) }\end{array}$ & 13,4 & 18,2 & 21,9 & 21,9 & 19,1 & 11,4 & 10,2 & 5,6 \\
$\begin{array}{l}\text { Caixa Econômica } \\
\text { Federal }\end{array}$ & 14,5 & 15,0 & 16,4 & 16,5 & 16,6 & 17,0 & 17,0 & 15,4 \\
\hline $\begin{array}{l}\text { Banco do } \\
\text { Brasil }\end{array}$ & 22,9 & 18,3 & 13,9 & 12,5 & 14,4 & 17,4 & 15,8 & 15,6 \\
\hline $\begin{array}{l}\text { Cooperativas de } \\
\text { crédito }\end{array}$ & 0,1 & 0,2 & 0,2 & 0,3 & 0,4 & 0,5 & 0,7 & 0,8 \\
\hline $\begin{array}{l}\text { Setor } \\
\text { bancário }\end{array}$ & 100,0 & 100,0 & 100,0 & 100,0 & 100,0 & 100,0 & 100,0 & 100,0 \\
\hline \hline
\end{tabular}

FONTE: Banco Central do Brasil.

(*) Excluindo os dois grandes bancos federais: Caixa Econômica Federal e Banco do Brasil.

participação de todos os outros segmentos ${ }^{25}$, mas em especial nas instituições públicas (ver tabela 5). O aumento de bancos estrangeiros no Brasil ocorreu, em maior extensão, em cima de bancos privados domésticos e, em menor extensão, sobre os bancos públicos (federais e estaduais). Embora exista uma tendência declinante na participação relativa dos bancos públicos, incluindo os dois "gigantes" federais, Caixa Econômica Federal e Banco do Brasil, sua participação relativa é ainda predominante no setor bancário com $36,6 \%$ do total de ativos no final de 2000, seguida dos bancos privados nacionais $(35,2 \%)$. Por outro lado, os maiores bancos privados domésticos no Brasil têm aumentado sua fatia de mercado no setor bancário via fusões e aquisições de bancos estaduais e privados, e, em menor extensão, por meio de crescimento orgânico. Conseqüentemente, o market share no setor bancário (total de ativos

25 Com exceção das cooperativas de crédito, cuja participação relativa, entretanto, é residual. 
dos bancos públicos e privados) dos quatro maiores bancos privados domésticos - Bradesco, Itaú, Unibanco e Safra - aumentou de 23,7\% em 1999 para 27,6\% em 2000, um aumento significativo de 3,9\% em seu market share em somente um ano (ver tabela 6).

O gráfico 1 mostra que entre os vinte maiores bancos privados no Brasil, sete são estrangeiros, incluindo os cinco maiores europeus - HSBC, ABN-Amro, Santander (BSCH), Sudameris e BBV Banco (BBVA) - e dois bancos americanos - Citibank e BankBoston, respectivamente dos grupos Citicorp e FleetBoston. Os doze maiores bancos privados retêm ao redor de $40 \%$ do total dos ativos do setor bancário (incluindo bancos públicos) e 78,3\% do total de ativos do setor bancário privado no final do ano 2000. Os cinco grandes bancos privados domésticos tinham $28,8 \%$ do total dos ativos, enquanto que os sete grandes bancos estrangeiros tinham $21,1 \% \mathrm{em}$

Tabela 6 - MARKET SHARE DOS 20 MAIORES BANCOS NO BRASIL (TOTAL DE ATIVOS) - 1999/2000*

\begin{tabular}{l|c|c|c|c}
\hline \hline \multicolumn{1}{c|}{ Conglomerado bancário } & $\begin{array}{c}\text { Origem } \\
\text { do capital }\end{array}$ & $\begin{array}{c}2000 \\
\text { R\$ milhões }\end{array}$ & $\begin{array}{c}2000 \\
\text { (\% total ativos) }\end{array}$ & $\begin{array}{c}1999 \\
\text { (\% total ativos) }\end{array}$ \\
\hline \hline Banco do Brasil & FE & 128.486 & 15,99 & 17,78 \\
CEF & FE & 126.080 & 15,69 & 17,01 \\
Bradesco+BCN+Credireal+Baneb+Boavista & PN & 87.503 & 10,89 & 10,10 \\
Itaú+Bemge+Banestado+Banerj & PN & 67.757 & 8,43 & 6,74 \\
Santander+Banespa & ET & 53.103 & 6,61 & 2,95 \\
Unibanco+Bandeirantes+Credibanco+Dibens & PN & 43.605 & 5,43 & 4,41 \\
ABN-Amro Real+ Bandepe & ET & 29.809 & 3,71 & 3,31 \\
Safra & PN & 22.632 & 2,82 & 2,45 \\
BankBoston & ET & 22.425 & 2,79 & 2,60 \\
HSBC & ET & 20.942 & 2,61 & 2,55 \\
Citibank & ET & 20.184 & 2,51 & 1,94 \\
Nossa Caixa & ES & 18.475 & 2,30 & 2,15 \\
Sudameris+América do Sul & ET & 15.332 & 1,91 & 1,95 \\
BBA Creditanstalt & PN & 10.451 & 1,30 & 1,26 \\
BBV & ET & 8.122 & 1,01 & 0,96 \\
Banrisul & ES & 7.723 & 0,96 & 0,88 \\
Votorantim & PN & 7.483 & 0,93 & n.a. \\
Mercantil de São Paulo & PN & 6.935 & 0,86 & 0,77 \\
Lloyds TSB & ET & 6.917 & 0,86 & n.d. \\
Chase Manhattan & ET & 5.329 & 0,66 & n.d. \\
\hline \hline
\end{tabular}

FONTE: Elaboração do autor com dados do Banco Central do Brasil.

(*) A tabela inclui somente instituições depositárias no Brasil (bancos comerciais, bancos múltiplos e caixas).

NOTAS: FE: bancos federais; PN: bancos privados nacionais (mais que 50\% das ações em mãos domésticas); ET: bancos estrangeiros; ES: bancos estaduais. n.d.: não disponível. 
dezembro de 2000 (ver tabela 6). Portanto, os bancos privados domésticos (Bradesco, Itaú, Unibanco, Safra e BBA) são ainda dominantes no segmento privado do mercado varejista, embora os bancos estrangeiros tenham agora uma importante presença no mercado bancário do país. ${ }^{26}$ Santander, em particular, depois da compra do Banespa, em novembro de 2000, tornou-se o maior banco estrangeiro no Brasil e o terceiro banco privado, entre o Itaú e Unibanco.

\section{Gráfico 1 - OS 12 MAIORES BANCOS PRIVADOS* (DEZEMBRO 2000)}

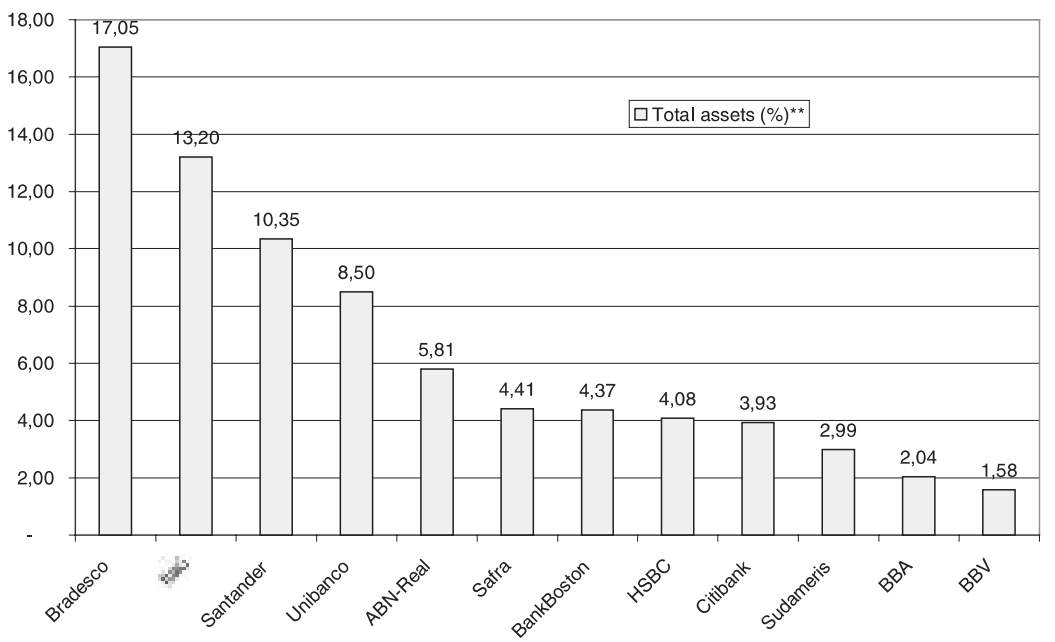

FONTE: Banco Central do Brasil.

(*) Inclui todos os bancos de cada conglomerado financeiro (ver tabela 6).

(**) Total de ativos: inclui somente bancos privados.

26 Se considerarmos a América Latina como um todo, a participação dos bancos estrangeiros no total dos depósitos pulou de 16\% em 1996 para 30\% em 1998 (CEPAL, 2000 , p. 161). Por outro lado, entre os 5 maiores bancos na região, existem 3 bancos estrangeiros e somente 2 nacionais. De acordo com os dados do website do Banco Santander do Brasil, em 2000, o BSCH tinha 10,6\% do total de ativos na região, BBVA 7,5\%, Bradesco 4,5\%, Citibank 4,0\%, Banamex 3,6\% (portanto, Citibank mais Banamex tinham juntos 7,6\% do total de ativos), e Itaú $3,1 \%$. 


\subsection{Estratégias de expansão dos maiores bancos europeus na} América Latina

Como visto na seção 3, a teoria de internalização da informação de Grubel não se aplica ao mercado varejista bancário, e isto é particularmente verdade no caso da recente onda de expansão dos bancos multinacionais para países emergentes. De fato, a maioria dos novos clientes dos grandes bancos europeus que se expandiram recentemente no Brasil - BSCH, BBVA, HSBC, ABNAmro e Sudameris (Intesa/Credit Agricole) - não tem nenhuma conexão prévia com as matrizes das firmas no país nativo de cada um desses bancos. De acordo com Focarelli e Pozzolo (2000), bancos que operam em países onde o setor bancário é grande e mais lucrativo devem ser capazes de exportar uma habilidade superior e são, assim, mais prováveis de expandirem suas atividades para o exterior. De fato, todos os maiores bancos europeus na América Latina - BSCH, BBVA, HSBC e ABN-Amro - aumentaram recentemente seu market share nos seus mercados domésticos via fusões e aquisições, alcançando uma posição de liderança ou quase liderança nesses mercados. ${ }^{27} \mathrm{~A}$ expansão para o exterior não é somente uma fonte de diversificação de receitas para esses bancos, mas também uma forma de eles fortalecerem sua posição no mercado bancário europeu no contexto das pressões competitivas resultantes da união econômica e monetária.

Existem algumas características comuns e distintas nas estratégias dos maiores bancos europeus na América Latina. Uma óbvia característica comum é que todos os quatro maiores bancos são grandes bancos universais que escolheram se expandir para o exterior como uma estratégia de expansão de suas atividades. Em 1997, os rendimentos no exterior representavam mais

27 Retomamos este ponto adiante. Somente para mencionar as mais recentes e importantes F\&As envolvendo esses bancos, HSBC comprou o Midland em 1992, elevando o total de ativos do grupo de $£ 86$ bilhões em 1991 para mais de $£ 170$ bilhões em 1992, criando uma das maiores organizações financeiras de sua espécie no mundo; $\mathrm{ABN}$ fundiuse com Amro em 1991 e obteve a liderança no mercado bancário nos Países Baixos; Santander fundiu-se com o Banco Central Hispanico (uma fusão anterior entre Banco Central e Hispanico) em 1999, tornando-se o maior grupo financeiro espanhol; a seguir, BBV (uma fusão anterior entre Bilbao e Vizcaya) fundiu-se com o Argentaria, formando o segundo maior grupo financeiro espanhol. Conseqüentemente, o setor bancário espanhol tornou-se um dos mais concentrados na Europa, formando uma espécie de duopólio, com o market share das duas maiores instituições crescendo de 33\% em 1987 para 50\% em 1996 (CEPAL, 2000, p. 158), e aumentando ainda mais depois das recentes fusões. 
que $35,0 \%$ do total de receitas desses bancos, ${ }^{28}$ e esta participação relativa aumentou no caso dos bancos espanhóis, por causa das suas recentes aquisições na América Latina.

Todos esses grupos financeiros estão procurando expandir suas atividades na Europa mais recentemente, como o caso da expansão do HSBC na França ${ }^{29}$, e do ABN-Amro na Itália. Eles estão também presentes em vários países latino-americanos, mas essa presença é desigual, como pode ser vista na Tabela 7. O total de ativos dos 20 maiores bancos estrangeiros na região é altamente concentrado em somente três bancos - BSCH, Citibank e BBVA - que englobavam 44,8\% do total de ativos de bancos estrangeiros na América Latina em 1998 (CEPAL, 2000, p. 61). Esses bancos são alguns dos poucos no mundo que têm obtido posições de liderança fora seus mercados originais. $\mathrm{O}$ market share desses bancos certamente aumentou, já que eles compraram alguns grandes bancos domésticos depois 1998, tais como o Bancomer pelo BBVA (junho de 2000), Serfin (maio de 2000) e Banespa (novembro de 2000) pelo BSCH, e Banacci (maio de 2001) pelo Citigroup. ${ }^{30}$ Ademais, eles são os únicos bancos com uma rede extensa de agências nos seis maiores países da região. ABN-Amro, embora com investimentos em diferentes países latino-americanos, somente no Brasil tem uma participação relativamente importante no mercado bancário, devido à compra do Banco Real em 1998. Já o Grupo HSBC, por sua vez, tem seus ativos concentrados nos três principais países da América Latina: México, Brasil e Argentina.

Deve-se observar também na tabela 7 que o Citibank - que pertence ao grupo Citigroup - tornou-se o segundo maior banco estrangeiro

28 As receitas no exterior em 1997 representavam, como percentagem das receitas totais, $63,8 \%$ no caso do HSBC, $52,8 \%$ para o ABN-Amro, 39,5\% para o Santander, e $38,2 \%$ para o BBV (NELLIS et al., 2000, p. 57).

29 De acordo com o Relatório Anual 2000 do HSBC, a aquisição do banco francês, CCF (Crédit Commercial de France) "foi um passo maior em direção a nossa estratégia de gerenciamento de riqueza e proporciona a nós uma plataforma substancial na zona do euro" (p. 3). De fato, com 692 agências bancárias, CCF é um dos maiores bancos na França.

30 O México assistiu a uma ampla reorganização das operações bancárias estrangeiras, em 2000/01, que mudou profundamente seu sistema financeiro, com o BSCH adquirindo o Grupo Serfin por US\$ 1,56 bilhões, o BBVA despendendo US\$ 1,85 bilhões para fundir suas operações mexicanas com o Grupo Bancomer, e, finalmente, o Citibank comprando o Grupo Banacci, a maior instituição financeira no México, em uma transação que envolveu um valor total de US\$ 12,5 bilhões. 
PAULA, L. F. de. Determinantes e impactos da recente entrada de bancos...

Tabela 7 - OS MAIORES BANCOS ESTRANGEIROS NA AMÉRICA LATINA POR ATIVOS (SETEMBRO DE 2000) - US\$ MILHÕES

\begin{tabular}{llrrrrrrrr}
\hline \hline Banco & \multicolumn{1}{c}{ Origem } & Argentina & Brasil & México & Chile & Colômbia & Venezuela & TOTAL & $\%$ \\
\hline \hline BSCH $^{*}$ & Espanha & 26.130 & 28.682 & 20.100 & 30.200 & 1.376 & 2.556 & 109.044 & 33,99 \\
Citibank** & USA & 10.429 & 8.798 & 42.590 & 6.350 & 1.137 & 686 & 69.990 & 21,81 \\
BBVA & Espanha & 9.174 & 5.004 & 37.300 & 4.900 & 2.811 & 3.700 & 62.889 & 19,60 \\
BankBoston & USA & 11.350 & 9.315 & 358 & 6.800 & 108 & - & 27.931 & 8,71 \\
HSBC & Reino Unido & 5.016 & 9.126 & 15.202 & - & - & - & 29.344 & 9,15 \\
ABN-Amro & Países Baixos & 2.801 & 15.581 & 154 & 2.900 & 110 & 95 & 21.641 & 6,75 \\
TOTAL & & 64.900 & 76.506 & 115.704 & 51.150 & 5.542 & 7.037 & 320.839 & 100,00 \\
\hline
\end{tabular}

FONTE: Elaboração própria com dados de Sebastian e Hernansanz (2000, p. 37); Banco Santander (Banespa-Brasil); e Gazeta Mercantil (Banacci-México).

NOTAS: (*) Incluindo Banespa, com dados de novembro de 2000.

(**) Incluindo Banacci, com dados de dezembro de 2000.

na América Latina depois da compra da maior instituição financeira no México, Banacci. Embora o Citibank esteja presente em todos os países importantes da América Latina há muito tempo, somente no México ele tem liderança de mercado. Historicamente, somente o Citicorp - e mais recentemente o HSBC - tem perseguido uma estratégia global no varejo bancário no mundo com presença em diferentes países e continentes, embora tenha uma tendência de focar seus negócios em cartão de crédito e serviços bancários para uma classe profissional urbana sem, até a aquisição do Banacci, tentar entrar no mercado varejista de massa, como os bancos espanhóis têm feito. Entretanto, o foco de seus negócios na América Latina é diferente do dos espanhóis, como destacado por Guillén e Tschoegl (2000, p. 10): "Os hispânicos estão competindo nos mercados de média e baixa renda, onde eles estão em competição com os maiores bancos domésticos. O único banco estrangeiro que tinha anteriormente feito uma incursão comparável, em termos de amplitude geográfica, na América Latina, foi o Citibank. Todavia, em contraste com os bancos espanhóis, o Citibank tradicionalmente focou seus negócios no mercado de mais alta renda, normalmente os segmentos $\mathrm{A}, \mathrm{B}$, e C1".

Os realmente grandes investidores estrangeiros europeus na América Latina são os dois grandes bancos espanhóis, que têm desenvolvido recentemente uma agressiva estratégia de expansão na região. BSCH e BBVA têm juntos mais que US\$ 170 bilhões de ativos na América Latina e ao redor de 55,8\% do total de ativos dos top 6 estrangeiros na região (ver tabela 7). $\mathrm{BSCH}$, depois da compra do Banco Serfin no México e do Banespa no Brasil, tornou-se o maior banco privado da região, com cerca de US\$ 109 bilhões de 
ativos. BSCH é o líder entre os bancos estrangeiros na Argentina, Brasil e Chile, enquanto que o BBva é o líder na Colômbia e Venezuela, e o segundo maior banco no México. A diferença em termos do total de ativos entre o BSCH e o BBVA na América Latina é devido, principalmente, ao Brasil, onde recentemente o $\mathrm{BSCH}$ comprou o Banespa e o BBVA tem apenas uma pequena fatia de mercado.

O ABN-Amro, no mercado bancário holandês, e o BSCH e BBVA, no mercado espanhol, cresceram substancialmente em seus mercados domésticos, perseguindo estratégias de crescimento baseadas em F\&As, de modo a obter uma posição de liderança em seus mercados nacionais. Essa política permitiu a eles aumentarem sua competitividade e alcançar o tamanho necessário para começarem um processo de expansão internacional. Depois que eles consolidaram sua posição no mercado doméstico (e algumas vezes ao mesmo tempo), expandiram-se para o exterior, provavelmente se preparando para o aumento na competição bancária no contexto da integração econômica e monetária européia. ${ }^{31}$ ABN-Amro, BSCH e BBVA são grandes bancos em sistemas financeiros de tamanho médio e altamente concentrados, que estão crescentemente expandindo suas operações para outros mercados, já que as alternativas domésticas são limitadas.

O Hong Kong Shanghai Bank-HSBC é uma das maiores organizações bancárias e de serviços financeiros no mundo. Como o Citigroup, o HSBC Group é um banco universal global com cerca de 6.500 escritórios em 79 países e territórios na Europa, na região do Pacífico na Saia, no continente americano, no Oriente Médio e na África. Somente em 1992, depois da aquisição do Midland, o grupo mudou seu domicílio de Hong Kong para Londres. HSBC é até hoje um banco fortemente enraizado na Ásia, a despeito de sua presença em todas as regiões do mundo. Entretanto, essa característica tem mudado desde a última década. Sua estratégia de managing for value enfatiza o equilíbrio dos negócios e receitas do grupo entre mercados

31 Em relação aos bancos espanhóis, Guillén e Tschoegl (2000, p. 68) destacam que ao final dos anos 80, "a competição [na Espanha] pelo market share intensificou e o governo encorajou fusões como uma forma de quebrar o cartel e se preparar para a integração européia. As margens de intermediação caíram e, embora ainda sólidos, os bancos passaram a se preocupar com a lucratividade de longo prazo. Além disso, entrando em novos mercados de produto - corretagem de ações, fundos de pensão e serviços de valor adicionado - vários dos grandes bancos começaram a ver a expansão internacional como uma forma de obter lucratividade explorando completamente suas habilidades". 
emergentes de rápido crescimento, maduros e mais antigos. ${ }^{32}$ De acordo com o Relatório Anual 2000, o grupo realizou 48,2\% de seus lucros na Ásia, 39,0\% na Europa, 9,6\% na América do Norte e 3,2\% na América Latina em 2000. A motivação de sua recente expansão para América Latina, assim como de outros investimentos em diferentes regiões, parece estar relacionada a uma estratégia de diversificação de riscos, por meio da diversificação geográfica de suas atividades, de modo que o banco possa se tornar menos dependente da Ásia.

\section{A REAÇÃO DOS BANCOS PRIVADOS NACIONAIS}

\subsection{Os efeitos da entrada de bancos estrangeiros sobre o mercado bancário nacional}

A literatura sobre os efeitos da entrada de bancos estrangeiros em mercados domésticos bancários (DEMINGUÇ-KUNT e HUIZINGA, 1998; CLAESSENS et al., 1998) mostra que, em termos gerais, essa entrada tem dois principais impactos:

a) primeiro, os bancos estrangeiros são menos eficientes do que os bancos domésticos nos países desenvolvidos, mas mais eficientes do que os bancos domésticos em economias emergentes. A fonte da eficiência superior em relação às instituições domésticas em países emergentes é diversificada, e a lista inclui a maior estabilidade dos bancos estrangeiros, $o$ mais fácil acesso a fontes estrangeiras de fundos, a maior propensão à inovação dos bancos estrangeiros, e, finalmente, ao fato de que eles têm, de forma geral, uma supervisão mais rigorosa em seu país nativo;

b) segundo, a entrada de bancos estrangeiros pode tornar os mercados bancários nacionais mais competitivos e, desse modo, pode forçar os bancos domésticos a operar de forma melhore mais eficiente, fazendo eles reduzirem suas despesas operacionais e, ao mesmo tempo, expandirem suas atividades.

32 A aquisição em 1999 da Republic New York Corporation e do Safra Republic Holdings reforçou a presença do HSBC nos países mais altamente desenvolvidos Estados Unidos, Suíça e Luxemburgo. 
Argumenta-se que os benefícios da entrada, em termos de serviços bancários aprimorados e de melhoria na regulamentação bancária, deveriam compensar os custos potenciais de entrada, relacionados ao fato de que as autoridades monetárias e reguladoras podem ter um menor controle sobre o setor bancário, caso haja uma presença estrangeira significativa no mercado doméstico (já que os bancos estrangeiros podem ser mais responsivos a mudanças nos requerimentos técnicos de capital dos reguladores de seu país nativo). Bancos estrangeiros penetram nichos e introduzem novos serviços para explorar oportunidades e, ao fazerem assim, aumentam a competição para os bancos locais. Para proteger o poder de mercado existente, as instituições financeiras domésticas podem se engajar em F\&As para se defender dos competidores estrangeiros potenciais.

Carvalho (2002) mostra, de acordo com dados recentes, que não existe nenhuma clara evidência de que os bancos estrangeiros têm sido mais eficientes do que os bancos privados domésticos e que o banco estrangeiro contribuiu para uma reorientação estratégica da atividade financeira, dando suporte ao setor privado no Brasil. Nossos achados dão suporte a esta hipótese. Por outro lado, existe alguma evidência de que a entrada de bancos estrangeiros tem tornado os mercados bancários mais competitivos, forçando os bancos privados domésticos a operarem de forma mais eficiente, ao mesmo tempo em que, como já visto, os maiores bancos têm participado ativamente do processo de consolidação no setor bancário brasileiro, provavelmente devido à pressão competitiva das aquisições dos bancos estrangeiros.

Dois indicadores podem ser usados para medir a eficiência de custo dos maiores bancos privados domésticos no Brasil: (a) eficiência operacional que, como o nome sugere, é usada para medir a eficiência operacional dos bancos, incluindo tanto as atividades de intermediação financeira como outras atividades não relacionadas diretamente à intermediação; (b) razão custo/ receita, um indicador usual para medir a eficiência bancária em sua tradicional atividade de intermediação financeira. ${ }^{33}$ Dois indicadores convencionais são usados para medir o desempenho dos bancos: retorno sobre patrimônio líquido - ROE - e retorno sobre ativos - ROA.

33 A definição precisa destes indicadores pode ser vista na Tabela 8. 


\subsection{O recente comportamento dos maiores bancos privados}

nacionais

A Tabela 8 apresenta alguns indicadores de eficiência e de desempenho dos três maiores bancos privados domésticos - Bradesco, Itaú e Unibanco - para o período 1997/2000, considerando o balanço patrimonial dos bancos múltiplos, mas não incluindo outras firmas de cada grupo. Esses bancos têm algumas características comuns: eles são grandes bancos universais e varejistas, com uma grande base de clientes e forte posição nas diferentes atividades financeiras (seguros, capitalização, cobrança, administração de cartão de crédito e de recursos de terceiros etc.), o que lhes permite desenvolverem atividades com vendas cruzadas. Portanto, eles são bancos com potencialidade para alcançar tanto economias de escala quanto de escopo, com efeitos positivos sobre sua eficiência operacional e lucratividade.

Os indicadores mostram, de forma geral, que existe uma melhoria no desempenho desses bancos mas nenhuma tendência clara no caso da eficiência bancária. Este último comportamento pode ser explicado parcialmente pelo efeito de curto prazo das aquisições recentes. O retorno sobre o patrimônio líquido dos três maiores bancos privados domésticos em 1997/2000 estava ao redor de 19,0\%, muito mais elevado do que o retorno de

Tabela 8 - INDICADORES DE EFICIÊNCIA E DESEMPENHO DOS TRÊS MAIORES BANCOS PRIVADOS NACIONAIS - 1997/2000

\begin{tabular}{|c|c|c|c|c|c|c|c|c|c|c|c|c|}
\hline & \multicolumn{4}{|c|}{ Bradesco } & \multicolumn{4}{|c|}{ Itaú } & \multicolumn{4}{|c|}{ Unibanco } \\
\hline & Dez.-97 & Dez.-98 & Dez.-99 & Dez. -00 & Dez.-97 & Dez.-98 & Dez.-99 & Dez.-00 & Dez.-97 & Dez.-98 & Dez.-99 & Dez.-00 \\
\hline Eficiência operacional* & $88,3 \%$ & $92,4 \%$ & $93,8 \%$ & $90,8 \%$ & $87,2 \%$ & $85,1 \%$ & $83,0 \%$ & $79,2 \%$ & $90,8 \%$ & $91,1 \%$ & $90,7 \%$ & $92,4 \%$ \\
\hline Razão custo/receita** & $75,7 \%$ & $72,3 \%$ & $78,4 \%$ & $76,4 \%$ & $78,9 \%$ & $74,7 \%$ & $73,9 \%$ & $67,6 \%$ & $73,8 \%$ & $67,5 \%$ & $64,9 \%$ & $68,8 \%$ \\
\hline Retorno sobre patrim. líquido (ROE) & $14,9 \%$ & $16,0 \%$ & $16,3 \%$ & $21,5 \%$ & $17,1 \%$ & $25,6 \%$ & $30,5 \%$ & $25,6 \%$ & $16,4 \%$ & $15,6 \%$ & $14,8 \%$ & $18,5 \%$ \\
\hline Retorno sobre ativos (ROA) & $2,0 \%$ & $2,1 \%$ & $2,0 \%$ & $2,7 \%$ & $2,0 \%$ & $3,3 \%$ & $4,4 \%$ & $3,2 \%$ & $1,7 \%$ & $1,7 \%$ & $1,9 \%$ & $1,8 \%$ \\
\hline Receitas emprest./Receitas financ.*** & $67,7 \%$ & $65,6 \%$ & $63,9 \%$ & $63,3 \%$ & $67,3 \%$ & $44,3 \%$ & $45,9 \%$ & $47,7 \%$ & $69,4 \%$ & $59,5 \%$ & $68,3 \%$ & $64,2 \%$ \\
\hline Receitas títulos/Receitas financeiras & $21,0 \%$ & $23,3 \%$ & $20,4 \%$ & $26,1 \%$ & $25,8 \%$ & $50,5 \%$ & $49,1 \%$ & $49,0 \%$ & $25,3 \%$ & $35,2 \%$ & $28,2 \%$ & $33,9 \%$ \\
\hline Receitas tarifas/Receitas financeiras & $20,5 \%$ & $18,7 \%$ & $16,9 \%$ & $27,7 \%$ & $41,6 \%$ & $22,9 \%$ & $31,5 \%$ & $32,3 \%$ & $18,4 \%$ & $16,7 \%$ & $15,6 \%$ & $19,2 \%$ \\
\hline
\end{tabular}

FONTE: Elaboração do autor com dados dos balanços dos bancos (somente bancos múltiplos) (*) Receitas operacionais (empréstimos + títulos + trade finance + depósitos compulsórios + serviços de tarifas + receitas das subsidiárias)/

Despesas operacionais (depósitos + empréstimos + provisão p/ devedores duvidosos + salários + overhead)

(**) (despesas de salário + overhead)/(margem bruta de intermediação + tarifas serviços bancários + provisão $\mathrm{p} /$ devedores duvidosos)

$(* * *)$ Receitas financeiras $=$ empréstimos + leasing + títulos + trade finance + depósitos compulsórios. 
12,0\% no setor bancário privado brasileiro em 1989/93. Itaú, o segundo maior banco privado, é o mais eficiente entre os top 3 no período, ao mesmo tempo em que apresenta níveis mais elevados de lucratividade. Sua estratégia tem sido a de ser o líder no desempenho, ainda que apresente um certo grau de conservadorismo no período analisado, com baixa exposição a empréstimos e lucratividade baseada principalmente em receitas de títulos (ver tabela 8), obtendo vantagens das altas taxas de juros no Brasil durante 1997/2000. Bradesco, o maior banco privado no Brasil, aumentou sua lucratividade (ROE) de 16,3\% em 1999 para 21,5\% em 2000. As perdas de receitas devido à queda nas taxas de juros domésticas em 2000 foram mais do que compensadas pelo forte aumento de $41 \%$ nas operações de crédito e leasing, um aumento de $32 \%$ nos fundos gerenciados pelo banco e, finalmente, um incremento de $25 \%$ nos depósitos (THE BANKER, março de 2001, p. 83). Unibanco, o quarto maior banco privado, tem tido seus indicadores de lucratividade não tão altos como o dos outros bancos, e uma das causas são suas elevadas despesas administrativas, que aumentaram depois da aquisição do Bandeirantes no ano 2000. O Unibanco tem tradicionalmente ocupado uma posição intermediária na lucratividade entre os grandes bancos brasileiros, com retornos sobre ativos e sobre o patrimônio líquido normalmente abaixo daqueles referentes ao Bradesco e Itaú.

Em resumo, os dados recentes mostram alguma evidência de que, ao menos no período recente, os bancos privados brasileiros estão obtendo um bom desempenho e os custos, se não estão decrescentes, têm estado sob controle. Isso parece sugerir que os top 3 obtiveram alguma eficiência na geração de receitas, embora seu bom desempenho possa ter sido inflado recentemente pela instabilidade macroeconômica no Brasil. Em outras palavras, este excelente desempenho - assim como dos outros bancos, sejam domésticos ou estrangeiros - foi possível em parte devido à deterioração nas condições de financiamento da dívida pública no Brasil, uma vez que os bancos têm sido os principais compradores dos títulos públicos federais (PAULA et al., 2001).

\subsection{Bancos privados nacionais versus bancos estrangeiros}

A tabela 9 apresenta alguns indicadores referentes à eficiência e desempenho de quatro bancos privados domésticos (Bradesco, Itaú, Unibanco e Safra), quatro bancos europeus (ABN-Amro Real, HSBC, Sudameris e BBV Banco) e dois bancos americanos (BankBoston e Citibank), com dados 
extraídos de um recente e extenso relatório escrito por analistas de banco do BSCH (GUIMARÃES et al., 2001). Infelizmente, o relatório não inclui dados do Banco Santander do Brasil, o banco estrangeiro líder no Brasil.

Os indicadores de eficiência em 1999/2000, em particular o índice de eficiência e a razão "receita líquida/empregados", apresentam um quadro em que os bancos domésticos tiveram, em média, uma pequena melhora nesses indicadores e um melhor índice comparado com os bancos estrangeiros, embora o subconjunto dos bancos americanos - Citibank e BankBoston - apresentem um melhor desempenho do que o subconjunto dos bancos europeus. Deve-se ter um certo cuidado, contudo, ao analisar esses dados. Primeiro, porque os três grandes bancos domésticos, como já assinalado, são grandes bancos varejistas, o que lhes permitem, ceteris paribus, colher os benefícios de economias de escala e escopo e, principalmente, de economias de rendas. Segundo, quando se compara os bancos europeus com os bancos americanos, deve-se considerar o fato de que os últimos têm seus negócios muito focado em um segmento seletivo do mercado varejista - private banking e corporate banking - assim como o fato de que eles não participaram da recente onda de fusões e aquisições no Brasil. Portanto, não tiveram problemas referentes à absorção de novos bancos. De fato, os bancos estrangeiros que fizeram recentes aquisições no Brasil ainda estão digerindo suas compras, o que significa que estão tendo grandes despesas em tecnologia, demissão de funcionário e limpeza dos empréstimos ruins no portfólio de crédito. Finalmente, de acordo com os

Tabela 9 - INDICADORES SELECIONADOS DE ALGUNS DOS MAIORES BANCOS NO BRASIL, 1999-2000

\begin{tabular}{|c|c|c|c|c|c|c|c|c|c|c|c|c|}
\hline & \multicolumn{6}{|c|}{ Eficiência } & \multicolumn{6}{|c|}{ Desempenho } \\
\hline & \multicolumn{2}{|c|}{$\begin{array}{l}\text { Indicador de } \\
\text { eficiência* }\end{array}$} & \multicolumn{2}{|c|}{$\begin{array}{c}\text { Emprega- } \\
\text { dos/agências }\end{array}$} & \multicolumn{2}{|c|}{$\begin{array}{l}\text { Receita liq./ } \\
\text { empregados }\end{array}$} & \multicolumn{2}{|c|}{$\begin{array}{c}\text { Retorno sobre } \\
\text { patrimônio }\end{array}$} & \multicolumn{2}{|c|}{$\begin{array}{c}\text { Retorno sobre } \\
\text { ativos }\end{array}$} & \multicolumn{2}{|c|}{$\begin{array}{c}\text { Margem líquida } \\
\text { de juros }\end{array}$} \\
\hline & 1999 & 2000 & 1999 & 2000 & 1999 & 2000 & 1999 & 2000 & 1999 & 2000 & 1999 & 2000 \\
\hline Bradesco & $70,41 \%$ & $65,62 \%$ & 7 & 7 & 20,6 & 32,0 & $16,32 \%$ & $21,50 \%$ & $1,38 \%$ & $1,83 \%$ & $7,19 \%$ & $7,12 \%$ \\
\hline Itaú & $66,12 \%$ & $66,54 \%$ & 15 & 16 & 49,6 & 50,9 & $31,65 \%$ & $27,71 \%$ & $3,60 \%$ & $2,65 \%$ & $7,56 \%$ & $7,09 \%$ \\
\hline Unibanco & $69,44 \%$ & $70,10 \%$ & 13 & 18 & 31,6 & 36,0 & $14,76 \%$ & $13,43 \%$ & $1,64 \%$ & $1,44 \%$ & $7,31 \%$ & $6,04 \%$ \\
\hline Safra & $61,40 \%$ & $54,16 \%$ & n.d. & 40 & n.d. & 88,5 & $19,33 \%$ & $22,11 \%$ & $1,10 \%$ & $1,32 \%$ & $4,91 \%$ & $4,01 \%$ \\
\hline ABN-Amro Real & $69,95 \%$ & $72,92 \%$ & n.d. & 15 & 9,2 & 13,3 & $10,32 \%$ & $5,47 \%$ & $1,04 \%$ & $0,93 \%$ & $6,34 \%$ & $13,17 \%$ \\
\hline HSBC & $79,27 \%$ & $94,20 \%$ & n.d. & 13 & n.d. & 9,7 & $25,76 \%$ & $21,48 \%$ & $1,84 \%$ & $1,21 \%$ & $10,39 \%$ & $8,02 \%$ \\
\hline Sudameris & $130,5 \%$ & $105,5 \%$ & n.d. & 18 & $-15,1$ & $-46,1$ & $-14,85 \%$ & $-38,28 \%$ & $-0,73 \%$ & $-1,83 \%$ & $3,36 \%$ & $4,31 \%$ \\
\hline BBVA & $78,40 \%$ & $87,42 \%$ & n.d. & 12 & n.d. & 13,8 & $28,49 \%$ & $9,25 \%$ & $2,12 \%$ & $0,67 \%$ & $6,49 \%$ & $5,29 \%$ \\
\hline Bank Boston & $49,41 \%$ & $52,78 \%$ & n.d. & 20 & n.d. & 131,0 & $22,23 \%$ & $20,57 \%$ & $1,19 \%$ & $1,16 \%$ & $8,27 \%$ & $5,83 \%$ \\
\hline Citibank & $38,25 \%$ & $76,30 \%$ & n.d. & 24 & n.d. & 92,8 & $48,45 \%$ & $19,37 \%$ & $4,02 \%$ & $1,43 \%$ & $11,79 \%$ & $3,95 \%$ \\
\hline
\end{tabular}

FONTE: Elaboração própria com dados de Guimarães et al. (2001).

NOTA: $(*)$ Índice de eficiência $=($ salários + overhead + tarifas $) /$ receita líquida de juros 
índices ROE e ROA, o desempenho dos bancos domésticos, com a exceção do Unibanco, é melhor do que o desempenho dos bancos estrangeiros. Uma vez mais existem diferenças na lucratividade dos bancos se for comparado o subconjunto de bancos europeus com os bancos americanos, já que estes últimos apresentam um melhor desempenho em 1999/2000. O melhor desempenho dos bancos domésticos pode ser explicado parcialmente pelo fato de que eles têm uma base maior de clientes, o que lhes proporciona um funding mais barato, de modo a dar suporte às suas operações ativas, de acordo com os achados de Guimarães et al. (2001).

Em síntese, ainda que as evidências não permitam extrair conclusões definitivas referentes ao recente comportamento dos bancos domésticos e estrangeiros, existe alguma evidência de que os três maiores bancos privados domésticos no Brasil apresentaram, ao menos em 1999/2000, melhores resultados nos indicadores bancários do que os bancos estrangeiros. Ademais, não existe nenhuma clara evidência de que bancos estrangeiros são mais eficientes do que bancos domésticos no Brasil. A reação ativa dos bancos domésticos à entrada de bancos estrangeiros, as diferenças culturais - já que os bancos locais estão mais adaptados às peculiaridades do mercado bancário brasileiro - e o alto nível de desenvolvimento e sofisticação do setor bancário no Brasil, que resultou de sua capacidade de se adaptar ao período de alta inflação, todos esses fatores considerados juntos, podem explicar esse comportamento. Os bancos brasileiros acostumaram-se a extrair vantagens do contexto de instabilidade macroeconômica, e isto tem sido particularmente possível devido às condições de financiamento da dívida pública no Brasil, combinando emissões de curto prazo com altas taxas de juros. Por outro lado, a entrada de bancos estrangeiros têm tornado o mercado bancário nacional mais competitivo, forçando os bancos domésticos a operarem de forma mais eficiente e expandirem suas atividades.

\section{CONCLUSÃo}

As principais conclusões que podem ser extraídas deste artigo são:

a) existem alguns impedimentos para fusões e aquisições dentro dos países da UE, e um incentivo para tal atividade fora da região. Um desses incentivos é a ausência de uma agência regulatória única na UE, que tem limitado os benefícios para 
os bancos se expandirem para áreas de atividades financeiras entre países. Assim, a despeito da uniformidade que deveria ter sido criada depois da Lei do Mercado Único e das várias diretrizes das comissões bancárias européias, e da introdução da moeda comum, dificuldades como diferentes regulamentações prudenciais nacionais têm tornado as operações entre países mais difíceis. Existem, ainda, múltiplas agências de supervisão dentro dos diferentes países e nenhuma agência de coordenação ou uma agência regulatória única dos bancos para a zona do euro. Conseqüentemente, as fusões e incorporações permanecem em boa medida confinadas dentro das fronteiras nacionais;

b) para alguns bancos europeus, a expansão para o exterior não é somente uma fonte de diversificação de receitas, como também um meio de se prepararem para o ambiente competitivo na zona do euro. A estratégia latino-americana pode ser interpretada como uma resposta a este ambiente mais competitivo, em que vários fatores têm erodido as receitas nos negócios bancários tradicionais;

c) a recente onda de internacionalização bancária é caracterizada não somente por instituições financeiras seguindo relações préexistentes - servindo principalmente a clientes oriundos do país onde o banco está sediado - mas também, e crescentemente, por uma maior integração com o mercado local. Assim, embora historicamente o padrão de participação acionária do banco multinacional seguiu a integração econômica entre países, hoje o atual padrão de expansão depende de um conjunto maior de fatores, do que somente o grau de integração econômica entre países. Nesse sentido, a teoria de internalização de Grubel que argumenta que a existência de contatos pessoais e canais de informação prévios entre bancos e as matrizes das firmas manufatureiras é a principal fonte de vantagem comparativa de um banco em um país estrangeiro - não se aplica à recente onda de expansão dos bancos estrangeiros no mercado bancário varejista nos países emergentes. Este é tipicamente o caso da América Latina e Brasil durante os anos 90, onde os bancos europeus - BSCH, BBVA, HSBC e ABN-Amro - têm tido predominantemente clientes locais com nenhuma conexão com as matrizes de firmas multinacionais no país de origem do banco; 
d) existem algumas evidências de que, ao menos no caso dos três maiores bancos domésticos privados, os bancos brasileiros têm reagido positivamente à entrada de bancos estrangeiros, já que têm participado ativamente da onda de F\&As e têm aprimorado sua eficiência e desempenho no período recente. Além disso, ao menos em 1999/2000, os top 3 nacionais apresentaram melhores resultados do que os grandes bancos estrangeiros. Portanto, não há nenhuma clara evidência de que os bancos estrangeiros sejam mais eficientes do que os bancos domésticos no Brasil no período recente. Os bancos privados nacionais têm algumas vantagens sobre os bancos estrangeiros que eles podem explorar, uma vez que eles estão mais adaptados às peculiaridades do mercado bancário brasileiro. Sua reação ativa à entrada de bancos estrangeiros no país, diferenças culturais e o alto nível de desenvolvimento e sofisticação do setor bancário no Brasil, que resultou de sua capacidade de se adaptar ao período de alta inflação, podem explicar este comportamento.

\section{RESUMO}

Este artigo objetiva analisar os principais determinantes e impactos da recente onda de bancos europeus no Brasil. A principal hipótese do artigo é que a onda de bancos europeus só pode ser entendida se forem considerados ambos os fatores externos e internos. Os determinantes externos estão relacionados ao processo de consolidação bancária no sistema financeiro europeu no contexto da União Monetária Européia, que tem estimulado alguns bancos a se expandirem para o exterior. Os determinantes internos, por sua vez, estão relacionados principalmente à gradual flexibilização das restrições legais, com respeito à presença dos bancos estrangeiros no setor bancário brasileiro. Finalmente, o artigo também avalia os impactos da entrada recente dos bancos europeus no mercado bancário varejista brasileiro. Neste particular, ele mostra que a entrada estrangeira tem afetado o mercado bancário doméstico, forçando os bancos nacionais a operarem de forma mais eficiente e também a expandir suas atividades, organicamente ou por fusões e aquisições. O paper conclui que não existe evidência de que os bancos estrangeiros são mais eficientes do que os bancos domésticos no Brasil no período recente, mas existe alguma evidência de que os 
maiores bancos privados nacionais têm reagido positivamente à entrada dos bancos estrangeiros.

Palavras-chave: consolidação bancária, bancos estrangeiros, setor bancário brasileiro.

\begin{abstract}
:
This paper aims at analyzing the main determinants and impacts of the recent wave of European banks entering Brazil. The principal hypothesis of the paper is that the wave of European banks can only be understood if one considers both external and internal determinants. External determinants concern the process of banking consolidation in the European financial system under the EMU that has stimulated some banks to expand abroad. Internal determinants are mainly related to the gradual flexibilisation of legal restrictions with respect to the presence of foreign banks in the Brazilian banking sector. Finally, the paper evaluates the impacts of the recent entry of European banks into the retail banking market in Brazil. In this particular matter, it shows that foreign entry has affected the national banking market, forcing domestic banks to operate more efficiently, and also to expand their activities organically or by mergers and acquisitions. The paper concludes that there is no clear evidence that foreign banks have been more efficient than domestic banks in Brazil in the recent period, but there is some evidence that the big private Brazilian banks have reacted positively to the entry of foreign banks.

Key-words: banking consolidation, foreign banks, Brazilian banking sector.
\end{abstract}

\title{
REFERÊNCIAS
}

ALIBER, R. Z. International banking: a survey. Journal of Money, Credit and Banking, v. 16, n. 4, p. 661-678, Nov. 1984.

BELAISCH, A. et al. Euro-area banking at the crossroads. IMF Working Paper, Washington, International Monetary Fund, n. 01/28, 2001.

BERGER, A. N.; DEYOUNG, R.; UDELL, G. F. Efficiency barriers to the consolidation of the European financial services industry, 2000a. Mimeografado.

BERGER, A. N. et al. Globalization of financial institutions: evidence from crossborder banking performance. FED Working Papers. $2000 \mathrm{~b}$. 
PAULA, L. F. de. Determinantes e impactos da recente entrada de bancos...

BIS. 70th Annual Report. Basel: Bank for International Settlements, 2000.

BOOT, A. W. European lessons on consolidation in banking. Journal of Banking \& Finance, v. 23, p. 609-613, 1999.

CARVALHO, F. C. New competitive strategies of foreign banks in large emerging economies: the case of Brazil, Banca Nazionale del Lavoro Quaterly Review, n. 213, p.135-169, June 2000.

CARVALHO, F. C. The recent expansion of foreign banks in Brazil: first results. Latin America Business Review, v. 2, n. 4, p. 93-119, 2002.

CASSON, M. Evolution of multinational banks: a theoretical perspective. In: JONES, J. (Ed.). Banks as Multinationals. London and New York: Routledge, 1990.

CEPAL Foreign Investment in Latin America and the Caribbean - 1999. Santiago: Chile, 2000.

CEPAL. Foreign Investment in Latin America and the Caribbean - 2000. Santiago: Chile, 2001.

CHASE MANHATTAN. The Chase Guide to Bank Bonds: Brazil. London: Chase Manhattan, 2000.

CLAESSENS, S.; DEMIRGUC-KUNT, A.; HUIZINGA, H. How does foreign entry affect the domestic banking market? World Bank Discussion Paper. Washington: The World Bank, 1998.

DEMINGUC-KUNT, A.; HUIZINGA, H. Determinants of commercial bank interest margins and profitability: some international evidence. World Bank Discussion Paper, n. 1900, March 1998.

EUROPEAN CENTRALBANK. Mergers and acquisitions involving the EU banking industry: facts and implications. 2000. Disponível em: 〈http://www.ecb.int>

FOCARELLI, D.; POZZOLO, A. F. The determinants of cross-border bank shareholdings: an analysis with bank-level data from OECD countries, 2000. Mimeografado.

FREITAS, M. C. Abertura do sistema bancário ao capital estrangeiro. In: Abertura do Sistema Financeiro no Brasil nos Anos 90. São Paulo: IPEA/Fapesp. 1999.

GRUBEL, H. The theory of multinational banking. Banca Nazionale del Lavoro Quarterly Review, n. 123, p. 349-363, Dec., 1977.

GUILLÉN, M. F.; TSCHOEGL, A. E. The internationalization of retail banking: the case of the Spanish banks in Latin America. Transnational Corporations, v. 9, $\mathrm{n}$. 3, p. 63-97, 2000.

GUIMARÃES, P.; MONTEIRO, F.; SANCHEZ, A. State, public and private: a complete travel kit to survive in Brazilian banking. Latin American Equity Research. São Paulo: BSCH, 2001. 
HAWKINS, J.; MIHALJEK, D. The banking industry in the emerging markets economies: competition, consolidation and systemic stability. BIS Papers, Basle: BIS, n. 4, 2001.

KREGEL, J. The prospects for European bank concentration in light of recent US experience. Latin America Business Review, v. 2, n. 4, p. 7-17, 2001.

MOLYNEUX, P. Does size matter? Financial restructuring under EMU, 2000. Mimeografado.

NELLIS, J.; MCCAFFERY, K.; HUTCHINSON, R. Strategic challenges for the European banking industry in the new millennium. International Journal of Bank Marketing, v. 18, n. 2, p. 53-63, 2000.

PAULA, L. F. R.; ALVES, A. J.; MARQUES JR. M. B. L. Ajuste patrimonial e padrão de rentabilidade dos bancos privados no Brasil durante o Plano Real (19941998). Estudos Econômicos, v. 31, n. 2, p. 285-319, abr./jun. 2001.

SEBASTIAN, M.; HERNANSANZ, C. The Spanish bank's strategy in Latin America, SUERF Studies, Viena: Societe Universitaire Europeenne de Recherches Financieres, n. 9, 2000.

WHITE, W. R. The coming transformation of continental European banking? Bis Working Papers, n. 54. Basle: Bank for International Settlements, 1998.

WILLIAMS, B. Positive theories of multinational banking: eclectic theory versus internalisation theory. Journal of Economic Surveys, v. 11, n. 1, p.71-100, 1997. 